


\title{
Ageism in the Media
}

\section{Online Representations of Older People}

\author{
Wenqian $\mathrm{Xu}$
}

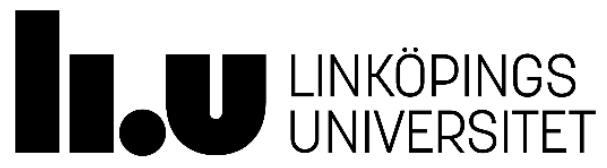

Division of Ageing and Social Change

Department of Culture and Society

Faculty of Arts and Sciences

Linköping University, Sweden

Linköping 2021 
Linköping Studies in Arts and Sciences No. 808

At the Faculty of Arts and Sciences at Linköping University, research and doctoral studies are carried out within broad problem areas. Research is organized in interdisciplinary research environments and doctoral studies mainly in graduate schools. Jointly, they publish the series Linköping Studies in Arts and Sciences. This thesis comes from Division of Ageing and Social Change at the Department of Culture and Society.

Distributed by:

Department of Culture and Society

Linköping University

58183 Linköping

Edition 1:1

ISSN: 0282-9800

ISBN: 978-91-7929-643-8

Author: Wenqian Xu

Title: Ageism in the Media: Online Representations of Older People

Cover photo by Wenqian $\mathrm{Xu}$

(cc) EY-sA This work is licensed under a Creative Commons Attribution-ShareAlike 4.0 International License.

(C)Wenqian Xu, 2021

Printed in Sweden by LiU-Tryck, Linköping 2021

Articles have been reprinted with permission of the respective copyright owners. 
To My Family and Friends 



\section{Abstract}

Ageism is a social problem that has harmful effects on the wellbeing of older people and needs to be tackled. It is pervasive and evident in the media (e.g., films, television, print and social media). Despite the fact that non-individual actors have adopted social media on a large scale in contemporary society, the social media representation of older people generated by those actors has remained insufficiently studied. This thesis aims to increase our knowledge of social media representations of older people and improve our understanding of ageism in the media. The knowledge obtained from this research can be used to inform policy and practice in terms of mitigating ageism in the media.

This thesis consists of four articles, which examine social media representations of older people generated by local authorities and media companies, with a particular focus on exploring how older people are represented in social media and how social media content about older people is produced. Articles 1, 3 and 4 present empirical analyses of social media texts about older people generated by Swedish local authorities and Chinese media companies, serving to identify the representations that may lead to ageism. Article 2 offers an empirical analysis of the production process for social media photos of older people within local authorities, serving to explore the ways in which stereotypical third-age representations are generated. This thesis employs the methods of content analysis and thematic analysis to examine representations of older people on various social media platforms (i.e., local-authority-managed Facebook pages, Tencent Video as a video streaming platform and Sina Weibo as a microblogging platform). It also employs the method of thematic analysis to analyse interview transcripts concerning the production of social media photos of older people within local authorities.

The results of the thesis reveal the complexity and nuances in the representation process and the meanings generated by those representations of older people on social media. More specifically, the thesis illuminates three ways in which the social media representations of older people lead to ageism: (1) the stereotyping of older people through signifying practice; (2) the generation and negotiation of the meanings surrounding older people among social actors with different 
power relations; and (3) the use of formal and informal rules within social media in the representation activities of mediatized institutions. A synthesis of the findings from the four empirical articles indicates a process of establishing the stereotypical third-age representation as a convention for social media, which can be seen as institutional ageism. The synthesis also indicates that this stereotypical third-age representation appears to be prominent in different contexts and across the various types of social media under examination. In this regard, it is necessary to promote knowledge and raise awareness about the risks associated with such representations of older people in the media. This thesis deepens our understanding of ageism in the media and generates evidence-based policy recommendations for media producers to inspire more thoughtful and reflexive media representations of older people and later life.

Keywords: Ageism, power relations, representations of older people, third age, social media logic. 


\section{Sammanfattning}

Ålderism är ett socialt problem som har negativa effekter på äldre människors välbefinnande och som därför behöver uppmärksammas och motverkas. Ålderism återfinns och skapas i alla typer av media (t.ex. filmer, tv, tryck och sociala media) genom det sätt på vilket äldre personer framställs i dessa sammanhang. Trots att en rad olika typer av organisationer idag använder sig av sociala medier, så har forskningen rörande mediarepresentationer av äldre personer än så länge varit inriktad på individers användning av sociala medier, medan representationer av äldre personer i organisationers sociala medier fått lite uppmärksamhet. Denna avhandling syftar till att öka kunskapen om hur äldre personer framställs i sociala media samt om ålderism i media. Förhoppningen är att kunskapen ska kunna bidra till att motverka ålderism i media, genom att påverka såväl policyer som praktik.

Avhandlingen består av fyra artiklar och delstudier som utforskar sociala media-representationer av äldre personer som skapats av lokala myndigheter och medieföretag med ett särskilt fokus på hur äldre personer framställs i sociala medier samt hur medieinnehåll rörande äldre personer produceras. Artikel 1, 3 och 4 omfattar empiriska analyser av sociala media-representationer av äldre personer som skapats av svenska lokala myndigheter och kinesiska medieföretag. Artikel 2 presenterar en empirisk analys av den produktionsprocess som föregår de stereotypiska tredje-ålder-representationer som i tidigare studier visat sig vara framträdande i lokala myndigheters sociala media. De metoder som i avhandlingen används för att analysera representationer av äldre personer och åldrande på olika sociala medieplattformar (dvs. lokala myndigheters Facebook-sidor, videoströmningsplattformen Tencent Video och mikrobloggplattformen Sina Weibo) är innehållsanalys och tematisk analys. Tematisk analys används även för att analysera intervjudata rörande den process som föregår att vissa - stereotypa-bilder av äldre personer är framträdande i lokala myndigheters sociala medier.

Avhandlingens resultat belyser komplexiteten och nyanserna i den representationsprocess och de betydelser som skapas av dessa representationer av äldre personer i sociala medier. Mer specifikt belyser avhandlingen tre sätt varigenom representationer av äldre personer i sociala medier kan leda till ålderism: (1) stereotypifiering av 
äldre personer genom betydelsebärande praktiker; (2) genom att innebörden av representationerna av äldre personer och åldrande framställs och förhandlas av aktörer med olika maktrelationer; och (3) genom mediatiserade institutioners användning av formella och informella regler för sociala media. En syntes av resultaten från de fyra empiriska artiklarna och delstudierna indikerar att en stereotyp tredje åldern-representation är framträdande i de olika organisatoriska sammanhang och de olika typer av sociala medier som studerats. Syntesen pekar därmed också mot att en stereotyp tredje åldernrepresentation kommit att blivit vedertagen i organisationers sociala media, något som kan ses som en form av institutionaliserad ålderism. Det är därmed av största vikt att främja kunskap och öka medvetenheten om de risker som är förknippade med representationer av äldre människor i sociala media. Avhandlingen fördjupar vår förståelse av ålderism i media och bidrar till att skapa evidensbaserade policyrekommendationer för medieproducenter i syfte att inspirera till mer genomtänkta och reflekterade medierepresentationer av äldre personer och åldrande.

Nyckelord: Ålderism, maktrelationer, representationer av äldre, tredje åldern, social medialogik. 


\section{Acknowledgements}

Throughout the writing of this thesis, I have received a great deal of support and assistance.

I would like to express my deepest appreciation to Annika Taghizadeh Larsson, my main supervisor, for her continuous support of my $\mathrm{PhD}$ study and research, as well as for her patience, encouragement, extensive knowledge and profound belief in my abilities. I would also like to extend my deepest gratitude to Lars-Christer Hydén for his guidance and constructive advice about this research work. Many thanks to Andreas Motel-Klingebiel for his unwavering support of my work. I am grateful to Ann-Charlotte Nedlund and Federica Previtali for their valuable comments at my 30-percent seminar. Thanks should also go to Monika Wilińska, Konstantin Economou and Susanne Kelfve for their constructive and insightful advice at my 60-percent seminar. I wish to thank Sara Mossberg Iversen, Magnus Nilsson and Johanna Sjöberg for their useful suggestions for improving my thesis summary. I also very much appreciate the study participants who took part in my interviews and made invaluable contributions.

I would like to extend my sincere thanks to my colleagues in the EuroAgeism programme for the stimulating discussions on ageism, for the days we worked together on various project outcomes, as well as for all the fun we have had over the last three years. Particularly helpful to me during my visit to Tampere University were Pirjo Nikander and Virve Kallioniemi-Chambers for their warmth, hospitality and generous support. I also had the great pleasure of working with Sabine Henning and Vanessa Steinmayer during my secondment at the United Nations ESCAP.

I wish to thank all the Division staff who have taken the time to discuss and enrich my work. Particularly valuable was the stimulating environment at the Division of Ageing and Social Change (ASC), and the experience will leave an impression far beyond this thesis. Special thanks to other PhD students for the peer support and corridor chats.

I gratefully acknowledge the funding received towards my $\mathrm{PhD}$ research from the European Union's Horizon 2020 research and innovation programme under the Marie Skłodowska-Curie actions (grant number 764632). I would also like to recognize that this research 
was accomplished within the context of the National Graduate School for Competitive Science on Ageing and Health (SWEAH), funded by the Swedish Research Council.

Last but not least, I would like to thank my family and friends. I am deeply indebted to my parents and grandparents for not only sharing their experiences of ageing but also supporting me spiritually throughout the writing of this thesis and my life in general. I wish to thank Björn for all the encouragement and inspirations, and thank Carlos for his enthusiasm, warmth and friendship.

Kista, Stockholm

April 2021 


\section{List of Articles}

I. Xu, W. (2020). (Non-)Stereotypical representations of older people in Swedish authority-managed social media. Ageing and Society. Advance online publication. doi:10.1017/S0144686X20001075

II. $\mathrm{Xu}, \mathrm{W}$. \& Taghizadeh Larsson, A. (Submitted). Communication officers in local authorities meeting social media: On the production of social media photos of older adults.

III. $\mathrm{Xu}, \mathrm{W}$. (Submitted). The stigma of dementia and the media: An analysis of reality shows about older people with dementia running a pop-up restaurant.

IV. Xi, W., Xu, W., Zhang, X. \& Ayalon, L. (2020). A thematic analysis of Weibo topics (Chinese Twitter hashtags) regarding older people during the COVID-19 outbreak. The Journals of Gerontology: Series B. Advance online publication. doi:10.1093/geronb/gbaa148 


\section{Abbreviations}

COVID-19 Coronavirus disease 2019

EU European Union

GDPR General Data Protection Regulation

ICTs Information and Communication Technologies

MIPAA Madrid International Plan of Action on Ageing

UN United Nations

UNECE United Nations Economic Commission for Europe

WHO World Health Organization 


\section{Contents}

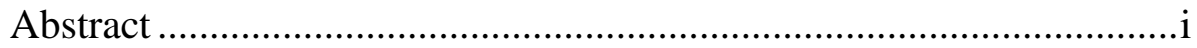

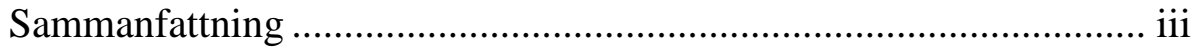

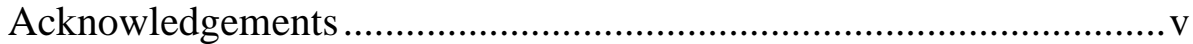

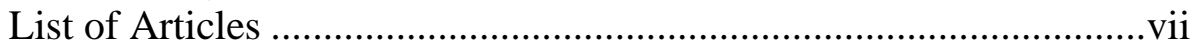

Abbreviations .............................................................................. viii

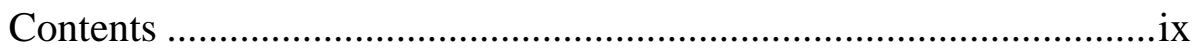

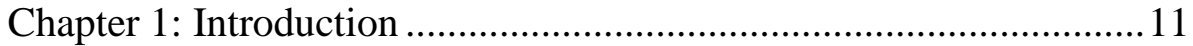

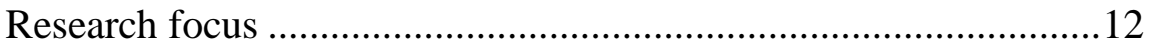

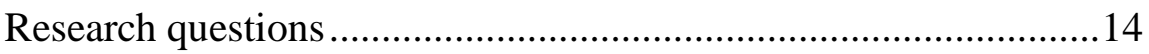

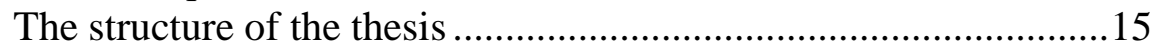

Chapter 2: Previous Research .......................................................... 17

Conceptual points of departure in research on media representation

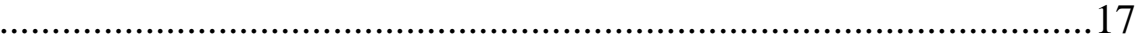

A reflectionist-representation perspective ...................................18

A constructionist-representation perspective .................................20

Social media adds complexity to representations of older people..25

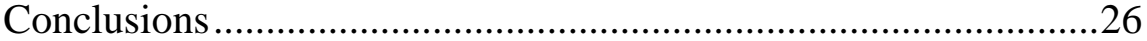

Chapter 3: Conceptual Framework .................................................29

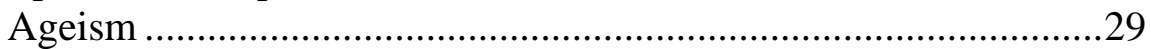

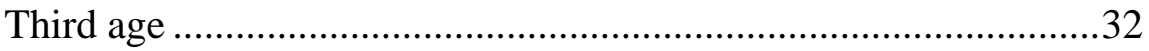

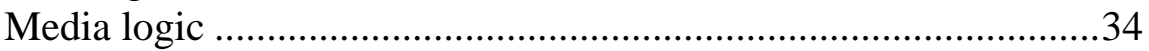

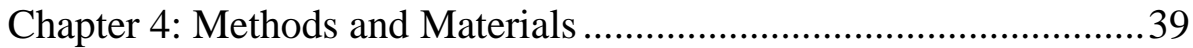

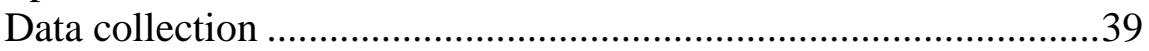

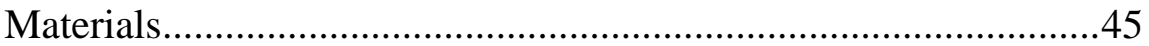

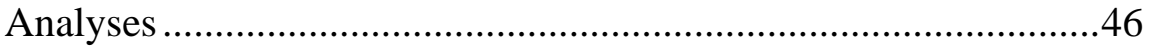

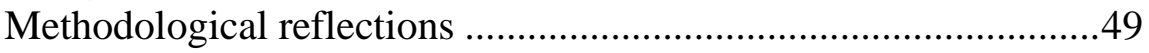

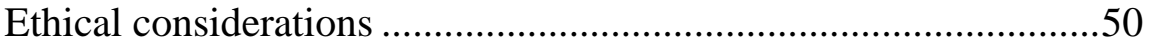

Chapter 5: Summary of Results ......................................................53

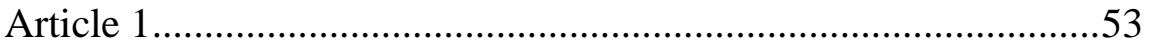

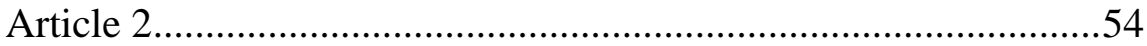

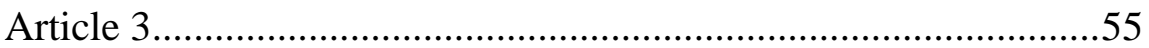

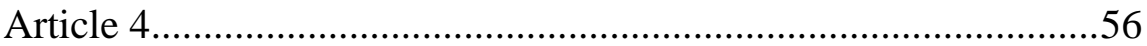

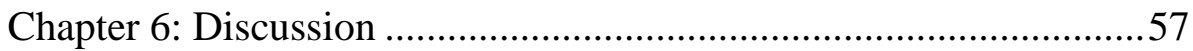

Social media representations of older people that lead to ageism ..57

Social media logic and the representation of older people ............60

Mitigating ageism in social media ...............................................62 


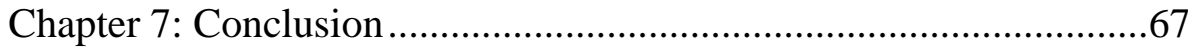

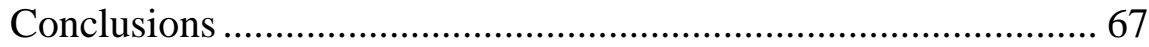

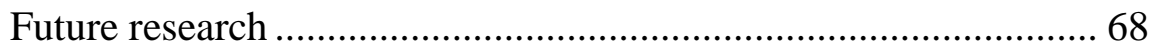

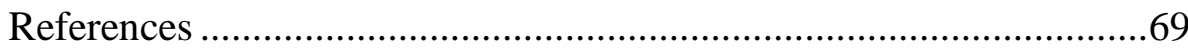

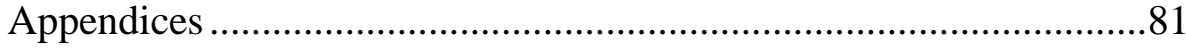

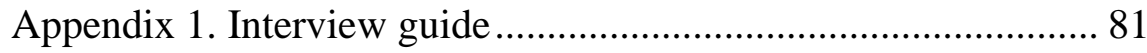

Appendix 2. Information letter and consent form ........................ 83 


\section{Chapter 1: Introduction}

The Madrid International Plan of Action on Ageing (MIPAA) is the most influential United Nations (UN) document focusing on older people ${ }^{1}$ published since 2002 . It serves as an international policy framework to commit UN member states to include ageing in social and economic development policies. This UN global action plan encourages society to move beyond the portrayal of stereotypes and to shed light on the full diversity of older people; it also calls for more positive images of older people that spotlight "the wisdom, strengths, contributions, courage and resourcefulness of older women and men, including older persons with disabilities" (United Nations, 2002: 51). Regional policy often emphasizes the significance of promoting realistic and heterogeneous portrayals of older people, as well as positive views of ageing (see UNECE, 2012). In general, people's attitudes tend to be more negative towards older people than younger ones (Kite et al., 2005). For instance, older people are often viewed as being "ill, mentally slower, forgetful, bothersome, sexually inactive, and unproductive" (Bai, 2014: 238). Negative images of older people can influence how they are treated by others via discriminatory practices, as well as affecting how older people view themselves and their own ageing (Centre for Ageing Better, 2020). The negative views of older people and the associated effects can be seen as manifestations and consequences of ageism.

Ageism refers to stereotyping, prejudice, and discrimination against people based on their age. It is often seen as a social problem that needs to be tackled. Since 2016, the World Health Organization (WHO) has taken the lead in developing a global campaign to combat ageism in the form of tackling "individual and social attitudes, stereotypes and behaviours towards people on the basis of their age, as well as the laws, policies and institutions that either perpetuate ageism or do little to stop it" (Officer \& de la Fuente-Núñez, 2018: 295). Ageism is pervasive and evident in many social institutions, such as work and employment,

\footnotetext{
${ }^{1}$ The terms, "older people," "older adults," "older persons" and "older individuals," are used interchangeably in this thesis. These terms are often used to refer to those aged 50 and over (Centre for Ageing Better, 2020). The notion of older people is subject to controversy in different national contexts and the research referenced in this thesis.
} 
health and long-term care, education, medicine, advertising and the media, and so forth (Ayalon \& Tesch-Römer, 2018).

The media, including films, television, print and social media, generally echoes and reinforces ageist images of older people (Officer $\&$ de la Fuente-Núñez, 2018; Soto-Perez-de-Celis, 2020). Researchers focusing on ageism in the media have approached the representation of older people by considering the textual, auditory, visual, and discursive aspects of media texts. Loos and Ivan (2018) argued that the representations of older people and the characteristics displayed in them are important for promoting social justice and power balance, given that these representations can produce and reproduce social perceptions of older people. Stereotypical representations of older people in the media can have a negative impact on their physical, mental, behavioural and social functioning (Bai, 2014). It has been argued that the media can reproduce negative social constructions that frame old age (Christensen, 2019), as well as serving to legitimate power relations and inequalities between age groups (Angus \& Reeve, 2006).

Tackling ageism in the media is often addressed as an important issue in policy and advocacy. In policy discourse, the media is often expected to be used to combat ageism by increasing the recognition of older people's contributions to family, community and society, as well as confronting negative images of older people (see United Nations DESA, 2016). In a recent report from the WHO (2020) as part of the global campaign to combat ageism, it is suggested that campaigners strategically and effectively use the media to change the narrative around ageing and older people. In this sense, research on the topic of Ageism in the Media can be relevant to inform policy and practice targeted at combating ageism.

\section{Research focus}

There has been a large body of studies investigating representations of older people in traditional media (e.g., print media, television, radio). Based on a semi-systematic review of the existing studies exploring representations of older people in the media, Swift and Steeden (2020: 31) found that negative representations dominated in print media (e.g., "older people as more of a burden than a benefit, as frail noncontributors to society"). Additionally, they identified that older people were mostly represented as "resource-rich and productive" in an overly 
positive light in entertainment media. However, social media representations of older people have remained insufficiently studied (Makita et al., 2021).

With the advancements in Information and Communication Technologies (ICTs), social media (e.g., social networking, videosharing, microblogging) could have become one of the social institutions that contribute to shaping the image of older people. OróPiqueras and Marques (2017) argue that social media has the potential to confront the dominance of negative representations of older people, because it allows individual users to effortlessly generate and share individualized experiences of growing and being old. Yet, social media was mostly found to be a constructor and distributor of age stereotypes, given that negative and offensive depictions of older people were evident on the social media platforms under investigation (see Levy et al., 2014; Makita et al., 2019; Vidovićová \& Honelová, 2018). Among these studies, the analyses mostly focused on social media representations of older people, old age or ageing generated by individuals.

There has been an observable and increasingly large-scale adoption of social media by non-individual actors. Various organizations (e.g., in the public sector, civil society and the for-profit sector) have increasingly introduced social media tools into the workplace and gradually incorporated them as part of their organizational work and activities. The adoption of social media by organizations is a relatively novel phenomenon in contemporary society. Jensen (2010: 59) envisioned that organizations at various levels would continuously develop digitally processed forms of representation and interaction, which has great potential to shape our understanding of society and culture. Given the prominent trend of social media adoption among organizations, the representations of older people generated by these relatively new non-individual social media adopters are worthy of study. Recent developments in social media use by local authorities and media companies have heightened the need to research the ways in which they represent older people in the social media texts they produce.

The focal point of this thesis is social media representations of older people generated by non-individual actors, including local authorities and media companies. It thus excludes the social media representations 
of older people generated by individuals. This thesis aims to increase our knowledge of social media representations of older people and improve our understanding of ageism in the media. The knowledge obtained from this research can be used to inform policy and practice in terms of mitigating ageism in the media. The overall objective of this thesis is to examine social media representations of older people generated by local authorities and media companies, with a particular focus on exploring how older people are represented and how social media content about older people is produced.

\section{Research questions}

The research questions of the thesis are formulated as:

RQ1: In social media photos, what signs, activities and contexts are associated with older people compared with other age groups?

RQ2: How do communication officers in local authorities produce social media photos of older people?

RQ3: In social-media-based reality shows, what specific views are expressed about older people with dementia?

RQ4: In social media hashtags, what dominant representations of older people can be identified?

The thesis encompasses four articles, each of which addresses one of the research questions. Each of the articles included in the thesis arises from a specific empirical setting with a research objective. The fulfilment of the research objectives assists in the achievement of the overall aim. The objective of Article 1 is to examine the ways in which local authorities have visually portrayed older people in their use of Facebook compared with other age groups. The objective of Article 2 is to investigate the production process for social media photos of older adults within local authorities from the perspective of multiple institutional logics. The objective of Article 3 is to explore how participants talk (or write) about older people with dementia in a socialmedia-based reality show. The purpose of Article 4 is to investigate the dominant representations of older people that can be seen in social media hashtags and how they have transformed during the COVID-19 outbreak. 
The structure of the thesis

The thesis has seven chapters. In the following, Chapter 2 (Previous Research) discusses the previous research on media representations of older people. Chapter 3 (Conceptual Framework) discusses conceptual definitions of ageism, the third age and media logic in order to establish the framework for the empirical analyses. Chapter 4 (Methods and Materials) introduces the data collection methods, materials and analyses performed in the research; additionally, it presents methodological and ethical reflections. Chapter 5 (Summary of Articles) presents the major findings of the articles included in this thesis. Chapter 6 (Discussion) presents a discussion of the results of the thesis and proposes policy recommendations for mitigating ageism in the media. Chapter 7 (Conclusion) presents conclusions and prospects for future research. 
Ageism in the Media 


\section{Chapter 2: Previous Research}

This chapter introduces the definition of the concept of media representation and describes two perspectives that have been used to study media representation in previous research. The chapter also discusses the previous research on media representations of older people conducted from these perspectives in order to explore the knowledge gaps in the field. It ends with conclusions addressing the potential contributions this thesis can make to increasing our knowledge of social media representations of older people and improving the understanding of ageism in the media. The thesis is positioned at the intersection of media studies and gerontology. Thus, the previous research presented in this chapter is drawn from both media studies and ageing studies.

\section{Conceptual points of departure in research on media representation}

In media studies, media representation traditionally refers to the way in which the media (e.g., newspapers and television) represents certain ideas, objects, events, groups of people and communities. While media research has long examined the representations of women and ethnic minority groups in a diversity of media contexts, the past few decades have seen an increased interest in researching media representations of older people ${ }^{2}$ and issues concerning ageing and later life.

From a theoretical point of view, the concept of representation has been argued to refer to a "primary" or "constitutive" process of making sense of the world and how it works (Hall, 1997). In media studies, Orgad (2012: 17, emphasis in original) argued that media representation refers to "texts (in the broad sense, which includes images) that circulate in the media space and carry symbolic content"; for example, Facebook pages, YouTube videos or trending Twitter topics. To distinguish media representations from other representational objects, Orgad (2012) claimed that the most important function of media representations is to give meaning to the things that happen in the surrounding world and to

\footnotetext{
2 The notion of older people is inconsistent across the previous studies referenced in this chapter. Older people can refer to either people aged 60 years and above (Lien et al., 2009; Williams, Wadleigh, et al., 2010), or people aged 50 years and above (Chen, 2015; Prieler et al., 2015; Szmigin \& Carrigan, 1999).
} 
capture "reality" in signs in some way. In this sense, media representation is understood as a process of meaning production in which media producers use signs to represent the surrounding world.

As introduced by Orgad (2012), the reflectionist-representation perspective and the constructionist-representation perspective are two fundamentally different ways to conceptualize representation as a process of meaning production in media studies. She argues that these two theoretical perspectives are linked to different views on the relationship between "reality" (the thing that is being represented) and "representation" (the act of representing it). Both these perspectives have been applied in previous research on media representations of older people. This section presents and discusses the previous studies examining media representations of older people from the two different theoretical perspectives on representation, as well as developing its own perspective on researching media representations of older people used in this thesis.

\section{A reflectionist-representation perspective}

There have been several media studies researching the representation of older people from a reflectionist perspective. The reflectionistrepresentation perspective suggests that language and visual images function akin to a mirror that reflects the pre-existing meanings of the "real" (Hall, 1997: 24). Orgad (2012: 18) argued that the reflectionist perspective, underpinned by the notion of the "historical truth value of photography," considers "a photograph as proof that something really happened, and belief, which runs deep in modern thinking in the photograph as an inherently objective medium of representation." The media representation studies that take a reflectionist perspective are mostly concerned with how accurate the representation is against "reality," based on the premise that representations reflect the meanings of a represented thing that already exists.

When it comes to previous media studies on the representation of older people, a large body of studies have adopted the notion that media representations of older people (need to) reflect the demographics of our ageing society. For instance, Amaral et al. (2019) argued that demographic changes are supposedly mirrored in the media when that media is considered to reflect society. It has been found that older people were invisible in a diversity of media contexts, which was then 
defined as an "under-representation" of older people in the media (Hiemstra et al., 1983; Kessler et al., 2004; Lee et al., 2007; Miller et al., 1999). Additionally, certain sub-groups of older people were found to be under-represented, such as older women (see Edström, 2018; Simcock \& Lynn, 2006; Zhang et al., 2006), older people of ethnic minorities (Roy \& Harwood, 1997), older people in certain occupations (Signorielli, 2004) and the oldest-old members of society (see Bonnesen \& Burgess, 2004; Miller et al., 2004). Bell (1992) problematized the wide gap between television demographics and the real demographics of the ageing society in the United States, as well as addressing the need to reflect other subtle divisions such as gender, race, class, marital status and health status in television portrayals of older people. Additionally, Bell acknowledged that television might not reflect the "reality" of the ageing society even where television demographics mirror the "real" demographics in terms of statistics, since the stereotypical representations of older people remain. In order to address some of these issues, several studies have advocated for new television programmes and advertising that reflect more "accurate" and diverse portrayals of older people (see Carrigan \& Szmigin, 2000; Cohen, 2002; Hiemstra et al., 1983; Milner et al., 2012). This indicates the idea that greater variety in the portrayals of older people can help to capture diverse views and opinions in our society and achieve a more "accurate" representation of older people in the media.

The reflectionist-representation perspective has received critiques confronting the view that representations are simply reflections of a preexisting reality. With a focus on visual representation, Orgad (2012: 20) argued that "the developments in digital photography and the increasingly accessible, affordable and easy-to-use image-altering software have substantially undermined the mimetic value of photographs." Even in journalism, which is expected to maintain objectivity, there have been discussions concerning whether and how journalism can depict reality accurately and truthfully based on fact (Porlezza, 2019). Given that various forces (e.g., market share, user experience) can distort what and how the audience perceives news reports, it could be a very difficult task to achieve an accurate and objective representation of older people in today's media space. 


\section{A constructionist-representation perspective}

There have been many studies in a variety of disciplines researching media representations of older people from a constructionist perspective. The constructionist-representation perspective considers "reality" to be the product of meaning production, which is different from the reflectionist perspective. Representations can be seen as signifying practice in various social contexts, and this involves the construction of social reality (Hall, 1997). In other words, the representing process includes the selection and exclusion of signs and symbols that stand for the reality conceived by a particular society and are influenced by people's values and beliefs. Orgad (2012: 20) maintained that media representation is "inherently and inevitably a construction, a selective and particular depiction of some elements of reality, which always generates some specific meanings and excludes others." Additionally, Orgad highlighted that the constructionistrepresentation perspective is concerned with how representations create meaning rather than how accurate they are in representing reality.

This constructionist perspective indicates that representation plays an active role in the production of meaning. From the constructionist perspective, meaning is understood as "shared or common responses, significations, intentions and goals, and, in general, the interpretive and representational processes that underlie human conduct" (Maines, 2000: 578, as cited in Blumer, 1969: 2). Dahlgren (1998) introduced four dimensions of meaning that are often examined in media and communication studies: denotational meaning and connotative meaning from a semiotic point of view, the existential dimension of meaning, as well as overarching dimensions of meaning within the broader societal landscape (e.g., social perceptions and identity formation). In this thesis, the overarching dimensions of meaning are at the core, including social perceptions of older people, the process of people making sense of older people and later life, and representation as a site of power struggles.

Previous media studies examining the representation of older people from a constructionist-representation perspective have investigated how older people are represented and assigned various specific meanings. Drawing upon the theoretical perspective of social semiotics and the work of Kress and van Leeuwen (2006), media representations of older people were analysed by using a semiotic approach that investigated the components of visual images of older people and how 
they produce meaning (see Kenalemang, 2021; Loos, 2018; Xu, 2019). The semiotic approach is also implicitly indicated in the scholarly discussion of the findings obtained from content analyses of media representations of older people. Research shows that older people have predominantly been portrayed in conjunction with certain commercial products in advertisements, such as food and beverages, financial products and insurance, health products and medicines (see Lee et al., 2006; Lee et al., 2007; Prieler et al., 2015). The connotations of concrete objects and physical settings presented in advertisements featuring older people were often further discussed. For example, Szmigin and Carrigan (1999) suggested that a limited range of products connote the incapacity of people in old age. Prieler et al. (2015) discussed the presence of the workplace setting by pointing out various forms of activities in which older people can participate. These studies cast light on the specific ways in which older people are represented in advertising and the media.

\section{Stereotypical representations of older people}

It has been found that older people are very often represented stereotypically and negatively (see Carrigan \& Szmigin, 2003; Meisner, 2020; Soto-Perez-de-Celis, 2020), indicating that the limited media representations give dominant meanings to older people in society.

The Stereotype Content Model $^{3}$ (introduced by Fiske et al., 2002) is often used as an analytical framework to examine media representations of older people along the dimensions of warmth and competence. For instance, Kroon et al. (2018) found that Dutch corporate media and newspapers represented older employees positively along the dimension of warmth and negatively along the dimension of competence (e.g., technological competence). Additionally, they argued that several identified representations of older people were not featured by either warmth or competence (e.g., the mentoring role stereotype and the costly stereotype). Sedláková (2005) found that some representations of older people in the nationwide Czech news cannot fit into the universal dimensions of the Stereotype Content Model, such as

\footnotetext{
${ }^{3}$ The Stereotype Content Model proposes two universal dimensions of social cognition (i.e., warmth and competence), which allows us to identify in-group members and foreign group members.
} 
representations of older people being "overburdens" of the pension system or "victims" of criminal offences.

Drawing upon the conceptual framework of social stereotypes of older people (proposed by Hummert et al., 1994), several previous studies have moved beyond positive/negative portrayals in a more general sense and attempted to identify specific stereotypes of older people that are (re-)produced by representations of older people in advertisements. Based on an analysis of television commercials from the 1950s to the 1990s in the United States, Miller et al. (2004) found that positive stereotypes of older people, such as the "Perfect grandparent," the "Adventurous golden ager" and the "Productive golden ager" were most common in the commercials. Based on a series of sorting-task laboratory sessions with advertisement consumers, multidimensional scaling and cluster analyses, Williams et al. (2010) identified four defined groups representing types of portrayals of older people in British magazine advertisements from 1999 to 2004, consisting of "Frail and Vulnerable," "Happy and Affluent," "Mentors" and "Active and Leisure-oriented" older people. Furthermore, Williams, Ylänne, et al. (2010) identified some representations of older people in these British advertisements that were in close alignment with stereotypes of older people held generally in Western societies. For instance, "Golden Ager," "Perfect Grandparent," "Mentor," "Coper," "Celebrity Endorser" and "Comedian" were found in the "positive" portrayals of older people, associated with traits such as being happy, active, wise and family oriented. These findings suggest that typed advertising portrayals often (re-)produce positive stereotypes of older people.

The previous studies into stereotypical representations of older people in the media mostly analysed media depictions of "older people" as a large group of adults over the age of 50/55/60/65, while not many previous studies have specified who these older people are or in which particular contexts they are represented. More research is needed to zoom in on some subgroups of older people (e.g., older people living with dementia, older people living in nursing homes) and to explore the ways in which they are represented in particular contexts.

As argued by Wykes (1998), the constructionist perspective can contribute to an improved understanding of the production of social meanings and power structures that legitimate knowledge. In this regard, 
relations of power are seen as an important aspect in the previous research examining media representations of older people from the constructionist-representation perspective. Orgad (2012: 25) argued that "power relations are encoded in media representations, and media representations in turn produce and reproduce power relations by constructing knowledge, values, conceptions and beliefs." With a focus on age-related power relations, Riley et al. (1972) argued that members of society may be stratified by age, whereby older people have a lower position in terms of property, power and prestige from the perspective of age stratification. Yet, media representations of older people were mostly analysed independently of other age groups in previous research. Given that social meanings and power structures are often reproduced by media representations, more research examining media representations of older people is needed to improve our understanding of these representations as a site of power struggles between social actors over the meaning of becoming and being old in a given society.

\section{Representations of the third age}

As shown in previous media studies on the representation of older people, the meaning generated by representations of third-age ${ }^{4}$ older people often contrasts with those representations of older people as being passive and dependent; for example, the binary opposing ideas of active/passive, independent/dependent. Orgad (2012: 30) argued that the "meaning generated by media representations relies heavily on this signifying practice, by which sets of binary oppositions construct opposing categories." In this regard, such signifying practices could probably lead to contrasting images of older people that are set off against each other and simplify the understanding of representations of older people as being either positive or negative.

Thus, from this perspective, future research should move beyond the documentation of positive/negative representations and instead pursue more nuanced depictions of how older people are specifically represented in a given context, as well as the extent to which such

\footnotetext{
${ }^{4}$ The third age is seen as a cultural field that is featured in consumer culture as well as ageing lifestyles and identities in contemporary Western societies (Higgs \& Gilleard, 2015). This concept is discussed in the next chapter, Conceptual Framework.
} 
representations are limited in various respects (e.g., social interactions, social space for interactions).

It has been found that representations of third-age older people in the media often involve particular constructions. For instance, Marshall and Rahman (2015) argued that the Canadian magazine for older people they analysed set forth an aspirational identity for third-agers as being fit, fashionable, functional and flexible, constructed to foster a particular perspective on successful ageing. Another study, by Loos (2013b), focusing on visual representations of older people, argued that using the concept of the third age enabled the Dutch authorities to construct a positive image of ageing (living longer and being healthier), serving to keep alive the myth of "eternal youth."

Previous studies have discussed the representation of older people in relation to third-age rhetoric or successful ageing discourse, which embodies the neo-liberal tenets of emphasizing individual responsibility and efforts for managing the risks in later life (see Loos \& Ivan, 2018; Ylänne, 2015; Ylänne et al., 2010). Some previous studies have problematized the media representation of third-age older people given the specific meanings generated. For instance, van Dyk et al. (2013) argued that the dominance of a stereotypical third-age representation marginalized older people with impairments and neglected to highlight the various different ways in which older people can contribute to society. They also argued that this dominance could also have the result of homogenizing older people as being a wholly active and healthy group, regardless of their heterogeneous lifestyles, living situations and personal pursuits. Moreover, Loos (2013b) argued that the representation of senior citizens as eternally youthful in public and private Dutch information sources can contribute to forming a new norm of ageing and creating a model for what defines an older person. Similarly, Christensen (2019) argued that the Danish advocacy group for older people aimed to promote positive and active ageing as well as generating online images of older people who still maintain an active and "younger" lifestyle. Resonating with the unfavourable implications of the successful ageing discourse for older people (Bülow \& Söderqvist, 2014), the representation of third-age older people also risks making older people feel responsible for compensating for the loss of resources in later life. The media producers of such representations appeared to create a new way of thinking about ageing and old age for 
those who wish to listen, while inadvertently neglecting the problems associated with these "overly positive" representations of older people.

Previously published studies on media representations of third-age older people (or so-called "extremely positive" representations of older people) have only explored the meanings generated by representations from the constructionist perspective, while not specifying how such representations are produced. In this regard, more research is needed to investigate the production processes of third-age representations.

\section{Social media adds complexity to representations of older people}

With the developments of ICTs and digitalization, the past few decades have seen the convergence of digital technologies and the emergence of digital media (often termed "new media"), which enables users to produce and consume content across platforms at any time (Jenkins, 2004). Technological convergence suggests a dynamic media space where social interactions have evolved via the trend towards digitalization. As a particular type of digital media, social media has become increasingly important in shaping public discourse on a wide range of topics and predicting real-world outcomes, given its ease of use, speed and reach (Asur \& Huberman, 2010). Drawing upon the previous definitions of social media from public relations, information technology and management scholarship, as well as the popular press, Carr and Hayes (2015: 50) defined social media as "Internet-based channels that allow users to opportunistically interact and selectively self-present, either in real-time or asynchronously, with both broad and narrow audiences who derive value from user-generated content and the perception of interaction with others." The common categories of social media include social networking sites (e.g., Facebook), media sharing sites (e.g., Instagram, YouTube), blogs and micro-blogs (e.g., Twitter), news aggregators (e.g., Reddit) and so forth.

Despite the fact that social media has become omnipresent in public life, representations of older people in such media have remained insufficiently studied (Makita et al., 2021). Among the existing and limited studies exploring social media representations of older people, they were found to be predominantly represented on Twitter as a disempowered, dependent, frail and homogeneous group (see JimenezSotomayor et al., 2020; Makita et al., 2019; Meisner, 2020; Soto-Perezde-Celis, 2020). These predominantly negative representations of older 
people might perhaps have come about due to several reasons. Levy et al. (2014) argued that young people prevalently hold negative stereotypes of older people and often participate in social media. They also pointed out the problem that Facebook administrators do not safeguard the content about older people to the same extent as they protect other social groups (in terms of e.g., sex, gender, race or ethnicity) (Levy et al., 2014).

Given the increasing adoption of social media by local authorities and media companies, these groups are currently part of the forces shaping social media representations of older people. So far, the social media representations of older people generated by these media producers have received scant research attention.

\section{Conclusions}

The research focus of this thesis is on social media representations of older people generated by local authorities and media companies. Based on a discussion of previous research on media representations of older people, this chapter concludes with a summary of the research gaps that need to be taken into account in the thesis: (1) Media representations of older people can create meaning about becoming and being old, as well as reproducing relations of power that determine those meanings in a given society. However, there has been insufficient analysis of media representations of older people from the constructionist perspective. (2) The research to date has mainly focused on exploring the meanings generated by media texts about older people, while few studies have investigated the production processes of these texts. In particular, little is known about the ways in which media professionals working within various collective entities (e.g., local authorities, media companies) produce media texts about older people, which can influence media representations of older people. In response to the identified research gaps, this thesis draws upon the constructionist perspective to examine social media representations of older people generated by local authorities and media companies, with a particular focus on exploring how older people are represented in social media and how social media content about older people is produced.

This chapter has discussed two major perspectives on researching media representations of older people that have been used in previous research; additionally, it emphasized the strengthens of the 
constructionist-representation perspective for exploring how representations of older people create meaning. This thesis draws upon the constructionist perspective and considers social media representations of older people as signifying practices and a site of struggles for power. Moreover, its inquiry moves beyond social media texts about older people, and rather investigates the production processes of these texts, which can shape the representation of older people. In so doing, the findings of the thesis will hopefully contribute to an improved understanding of ageism in the media by examining social media representations of older people generated by local authorities and media companies. The next chapter, Conceptual Framework, describes the theoretical foundations that help to achieve the analyses of social media representations of older people and discusses the findings in relation to ageism. 
Ageism in the Media 


\section{Chapter 3: Conceptual Framework}

Based on the findings of Chapter 2, this chapter introduces the conceptual framework used in the thesis to research social media representations of older people. The chapter firstly develops the conceptual understanding of ageism that is used to discuss the social media representations of older people and identify those representations that may lead to ageism. It also introduces the concept of the third age, which is used to name a certain type of ageist representations. Finally, the chapter presents the concept of media logic, which is used to research the production process of media content about older people.

\section{Ageism}

The concept of "age-ism" was coined by Robert N. Butler in 1969 and initially referred to the prejudice held by one age group towards another. Butler (1975) later refined the concept as a process of systematic stereotyping of and discrimination against people because they are old, which is often seen as the classic way of defining ageism. Based on a recent review of the conceptual development of ageism over the past several decades, Iversen et al. (2009: 4) suggested a definition of the concept listed in the following, which was aimed at establishing the "foundation for higher reliability and validity in future research" about ageism as well as offering "a new way of systemizing theories on ageism."

Ageism is defined as negative or positive stereotypes, prejudice and/or discrimination against (or to the advantage of) elderly people on the basis of their chronological age or on the basis of a perception of them as being "old" or "elderly." Ageism can be implicit or explicit and can be expressed on a micro-, meso- or macro-level. (Iversen et al., 2009:15)

However, Snellman (2016) argues that this definition can provide a reductionist understanding of ageism due to several pitfalls in the definition; for instance, it presents itself as a concept relating exclusively to older people and distinguishes older people from the rest of us. He mentioned additional conceptual ways of defining and understanding ageism, such as ageism as an ideology, ageism as a form 
of culturally based age bias, and ageism as a socially constructed phenomenon in ongoing constitutive processes (Snellman, 2016: 152).

As a contribution to the conceptual understanding of ageism from media and communication researchers, Loos and Ivan (2018: 164) coined the concept of "visual ageism" to describe "the social practice of visually underrepresenting older people or misrepresenting them in a prejudiced way." This conceptual understanding of ageism is concerned with visual depictions of older people in documents, photos and videos, as it resulted from their literature review of empirical studies focusing on visual images of older people in Western print and television advertisements and television programmes.

From the constructionist perspective that this thesis draws upon, it is possible to discern that there are two shortcomings in the current definition of visual ageism.

Firstly, the conceptual definition of visual ageism indicates the reflectionist perspective on media representation, with the premise that the media should reflect the demographics of society. Drawing on Stuart Hall's (1997) academic work on representation, Dixon (2019) claimed that media products create versions of "reality" that are influenced by the subjective views of their producers, which suggests that media products do not offer accurate reflections of the world. In this sense, the process of selection and exclusion seldom leads to reflective (or accurate) representations of older people.

The second concern about the concept of visual ageism is that it can be seen as a concept that is exclusively about older people and thus might create an us/them dichotomy. Its emphasis on media representations of older people could direct researchers to focus on the aspect of ageism against older people and to limit their empirical studies to a certain age group. In contrast, Bytheway (1994) argued that ageism should preferably be understood as an issue for people of all ages. Thus, there is a need to recognize visual ageism as a concept that affects everyone.

The following presents the conceptual understanding of ageism that is used to examine media representations of older people in the present thesis.

The thesis integrates the classical definition of ageism with the definition of visual ageism in order to focus on the stereotypical representations of older people in the media that may lead to ageism. 
Gorham (1999: 232) argued that "those who are in a dominant social position have the power to define the dominant understandings and thus have tremendous ability to make their definitions appear natural and unarguable." In this respect, the stereotypical representation of older people could be understood as one of the manifestations of ageism in the media. With special focus on today's media space, content can appear in all of its manifestations (visual, textual, auditory and digital property). Stereotypical representations of older people may thus manifest in visual and many other aspects.

This thesis also casts light on the power dimensions inscribed in or reproduced by media representations of older people. Ageism in the media is understood as the social practice of signifying asymmetrical power relations within a given society. Specifically, two dimensions of power relations are highlighted when studying media representations of older people. One of these is the relations of age power. In Western societies, young and older adults tend to have lower status in terms of power, prestige and influence (Palmore, 2016). Thus, the distinctions between older people and other age groups in media representations may reproduce these power relations among age groups, or between young and old. The other power dimension is power in relation to temporality. As argued by Krekula et al. (2018: 41), this power can be "practiced through notions of how life ought to be lived and through norms of what is considered a natural consequence and time for different phases in life." Angus and Reeve (2006) pointed out a form of ageism that refers to the overly positive visions of being old that are difficult for many older people to achieve. It has been argued that the third-age rhetoric and active ageing discourse carry a selected meaning for how older people should live in later life and what lifestyle they should adopt. For instance, Ranzijn (2010) argued that the notion of active ageing might oppress older people who are already disadvantaged because it can homogenize living conditions and devalue the different life experiences of older people. As argued by Marhánkova (2010), the active ageing approach implies that people should take action to positively influence their personal ageing processes by addressing self-responsibility and self-care. Meanwhile, van Dyk et al. (2013) argued that it creates a new normal of ageing which appears to be the prototypical model of "best ager." This perspective on the power dimension should be paid special attention when analysing the 
meanings generated by media representations of older people. The stereotypical third-age representation is an example of ageism in the media that can be addressed in terms of both stereotypes and power dimensions.

\section{Third age}

The original concept of the third age was introduced in the academic work of Laslett (1991). In his book, A Fresh Map of Life, about the emergence of the third age, Laslett (1991) located the appearance of the third age within the history of society and sought to dismiss the marginalization of old age. This concept is also linked to the "youngold" category proposed by Neugarten (1968). The concept of the third age is often seen as a life stage of old age which is qualitatively different from the fourth age. Considering the characteristics of these two life phases, the third age refers to the phase when people's engagement, independence and personal fulfilment are sustained, while the fourth age is the phase that features negative attributes such as infirmity, decline, dependence and death (Kydd et al., 2018; Rowland, 2012).

From the perspective of cultural gerontologists, the third age has developed as a cultural field that defines a post-retirement identity in Western societies, "shaped by the experiences of people who grew up and are now growing old within mass consumer society" (Gilleard and Higgs, 2010: 122). Specifically, Gilleard and Higgs (2011) argued that the third age's emphasis on choice, autonomy and self-expression originated from the 1960s youth culture of the post-war baby boomers who grew up in a mass consumer society and have now entered retirement, indicating the development of generational lifestyles. They articulated the boundaries of the third and fourth ages in the following quotation; meanwhile, they highlighted that people who do not take part in the third age for any reason are not automatically transferred to the fourth age (Gilleard \& Higgs, 2010).

Part of the definition of the third age is its active exclusion of "old age" and "agedness". In that sense the cultural and structural boundaries of the third age may provide, through a process of antagonistic reciprocity, the structural boundaries for the "fourth age". But this active exclusion of agedness reflects as much as it determines the fourth age, appearing as a kind of distortion in the mirror of the third age. (Gilleard \& Higgs, 2010: 122) 
As a concept that is often associated with the third age, the fourth age is conceptualized as a form of "social imaginary" of later life characterized by otherness and negativity, which emerges from the institutionalization of infirmity within long-term care (Gilleard and Higgs, 2014a). Higgs and Gilleard (2015) further positioned the fourth age as an undesirable "re-imagined old age" without agency, which is fashioned by discourses of frailty and vulnerability associated with old age, as well as by the powerlessness of people who cannot lead a desirable later life. Wahl and Ehni (2020) argued that this conceptualization of the fourth age could be "ethically questionable" because it abandons fundamental and meaningful human values, such as agency and liberty. Additionally, they highlighted the need to use the third/fourth age concepts with a critical attitude or avoid using them altogether.

This thesis draws upon the conceptual understanding of the third age developed by cultural gerontologists to examine social media representations of older people. As illustrated in the chapter on Previous Research, the concept of the third age has often been used to pinpoint media representations of older people that serve to dismiss the marginalization of the old and construct an active ageing lifestyle. The development of the third age by cultural gerontologists can help this thesis to apply the third/fourth age distinction and draw special attention to the construction of the third age within the discourse of social media representations of older people.

Given that this thesis focuses on social media representations of older people, the combination of concepts and theoretical paradigms from both gerontology and media studies can help to advance the fundamental understanding of representations of older people in social media as well as mitigating ageism in the media whose solutions are beyond the scope of a single discipline. As part of the conceptual framework, the gerontological concepts (i.e., ageism and the third age) discussed above serve as the guiding perspective to explain the findings about social media representations of older people within the developed framework. Drawing upon media studies, the following section introduces the conceptual understanding of media logic that informs the research investigating the way in which social media content about older people is produced from the perspective of multiple institutional logics. 


\title{
Media logic
}

It has been argued that the media has emerged as an autonomous entity with "a certain degree of autonomy and a distinct identity" which constitutes "the framework for human communication and action in a given sphere of human life at a given time and place" (Hjarvard, 2008: 116). The thesis draws upon the institutional perspective on the media (see Hepp, 2012; Hjarvard, 2014; Krotz, 2009; Livingstone \& Lunt, 2014) and contends that the media (in the forms of interactive and mass media) has emerged as an independent social institution with its own logic.

The concept of media logic was first introduced by Altheide and Snow (1979) as a way to describe the logic of mass media (e.g., print media, television and radio) during the second half of the twentieth century. Their definition, as shown in the following, suggests that they considered media logic to be a formatting logic that functions to choose the mode of presentation and interpretation, as well as selectively presenting social phenomena in the media.

\begin{abstract}
Media logic consists of a form of communication; the process through which media present and transmit information. Elements of this form include the various media and the formats used by these media. Formats consist, in part, of how material is organized, the style in which it is presented, the focus and emphasis on particular characteristics of behaviour, and the grammar of media communication. Format becomes a framework or a perspective that is used to present as well as interpret phenomena. (Altheide \& Snow, 1979: 10)
\end{abstract}

This conceptual understanding of media logic has been used to improve the understanding of the ways in which material and symbolic resources are organized in the mass media, especially news media in Western societies. Strömbäck (2008) argued that news media logic is characterized by news values and storytelling techniques, which determine the way in which news materials are organized and social experience is represented. Schrott (2009) argued that news norms (independence and objectivity) and professional standards have emerged and become established endogenously, suggesting the institutionalization of news media logic (as an evolutionary process). With technological advances, Finnemann (2011: 73) argues that both mass media and other social institutions adapt to "new digital media 
and related institutional forms, to new narrative formats, new institutional forms and to new business models as well."

Social media platforms have increasingly been seen as institutions with their own logic, which functions to produce a distinctly different form of mediated communication compared to traditional mass media. For instance, Klinger and Svensson (2015) proposed a network media logic consisting of central elements (i.e., rules/format of communication in terms of media production, dissemination and use). Additionally, Van Dijck and Poell (2013) addressed the impacts of social media on people's informal interactions, institutional structures and professional routines, as well as introducing the concept of social media logic with its own institutional norms, strategies, mechanisms and economies. Drawing upon Altheide and Snow's (1979) conceptual understanding of media logic, this thesis assumes that social media logic may perhaps format the mediated messages that circulate on social media platforms. This has been supported by existing empirical evidence, such as political interactions on Facebook and Twitter in Western democracies (Kalsnes et al., 2017) and academic interactions on Academia.edu (Duffy \& Pooley, 2017). Since social media logic can be seen as a formatting logic that determines the choice of presentation mode and the portrayal of social experience on social media platforms, this conceptual understanding of media logic fits into the constructionist perspective of studying representations of older people in social media. In this thesis, I have applied this conceptual understanding of media logic to analyse how older people are represented in social media, whereby age understandings and age power within a society are signified.

Hjarvard (2008) further develops Altheide and Snow's (1979) conceptual understanding of media logic by refining it as the institutional and technological modus operandi of the media. This implies an institutional perspective on the media and its interactions with culture and society. Hjarvard (2008) also characterized a given situation in the development of society and culture in which the media interacts with other social institutions (e.g., politics, religion, education, science, public bureaucracy), which was termed mediatization.

Mediatization is to be considered a double-sided process of high modernity in which the media on the one hand emerge as an independent institution with a logic of its own that other social 
institutions have to accommodate to. On the other hand, media simultaneously become an integrated part of other institutions like politics, work, family, and religion as more and more of these institutional activities are performed through both interactive and mass media. (Hjarvard, 2008:113)

This conceptual understanding of media logic draws special attention to the influences of media logic on "the nature and function of social relations as well as the sender, the content and the receivers of the communication" (Hjarvard, 2008: 113). It also inspires empirical research analysing the processes by which the media influences other institutions or social spheres of human activity (Strömbäck \& Esser, $2014 b$ ). With a focus on the institutional context of public authorities in Western democracies, one study (Olsson \& Eriksson, 2016) found that social media logic led public authorities to invest resources in channels that involved relatively few citizens who were favourably inclined towards the authorities, to increase communicative and imagebuilding power, and to participate in more personalized communication (e.g., a stronger presence of individual employees, informal communication styles). In this regard, Hjarvard's conceptual understanding of media logic's interplay with others is of particular importance for the present thesis. It is necessary to keep in mind the potential influence of social media logic over the authorities when analysing media production and the circulation of meanings of older people and later life within local authorities in contemporary society.

Given the focus of this thesis on social media representations of older people, social media logic is relevant to the inquiry. Van Dijck and Poell (2013) argued that social media logic (consisting of norms, strategies, mechanisms and economies) has gradually permeated all areas of public life, as well as changing the conditions and rules of social interaction. Additionally, they proposed four grounding elements of social media logic: datafication, programmability, connectivity and popularity. Specifically, Van Dijck and Poell (2013) argued that datafication is the fundamental principle of social media logic, referring to the capability of turning content, relationships and behaviours into data. They described programmability as "the ability of a social media platform to trigger and steer users' creative or communicative contributions, while users, through their interaction with these coded environments, may in turn influence the flow of communication and 
information activated by such a platform" (Van Dijck \& Poell, 2013: 5). Connectivity was explained as "an advanced strategy of algorithmically connecting users to content, users to users, platforms to users, users to advertisers, and platforms to platforms" (Van Dijck \& Poell, 2013: 9). Popularity was argued to be the techniques of social media platforms for promoting the visibility of people and notions, which can be measured in quantified terms; for example, Twitter's trending topics and YouTube's most viewed videos (Van Dijck \& Poell, 2013).

The specification of the elements of social media's logic allows analyses of the ways in which these elements impact upon the practices of its users and institutional communication on social media. In this regard, social media logic can help us to understand the production processes relating to content about older people within non-individual entities using social media. Thus, this thesis draws upon the conceptual definition of social media logic from Van Dijck and Poell (2013), which has been commonly used in social media studies (e.g., Enli \& Simonsen, 2018; Haim et al., 2021; Hermida \& Mellado, 2020; Kalsnes et al., 2017; Olsson \& Eriksson, 2016) and underscores the role played by social media architecture in shaping users' practices.

To analyse the interplay between social media and other social institutions, a perspective of multiple institutional logics provides a framework within which the interplay between institutional logics can be studied. A body of institutional analyses suggests that multiple institutional logics may co-exist within any given institutional context and that a perspective of multiple institutional logics can be taken into account in order to distinguish the appropriate rules, beliefs and behavioural norms associated with the different institutional logics to be found in that context (see Kyvik \& Stensaker, 2016; Petersen, 2017). Thornton and Ocasio (2008) argued that a perspective of multiple institutional logics helps to comprehend individual practices within a social context, which legalizes behaviour and offers opportunities for the agency. Scott $(2003,2014)$ argued that an institutional logic comprises four aspects (artefacts, routines, symbolic systems and relational systems). These four aspects "provide the routes whereby a particular logic enters organizational contexts and processes, forming the platform for the translation of this logic in relation to ongoing work activities, actors and motives" (Pallas et al., 2016: 1664). This suggests 
the arenas where media logic potentially interacts with other institutional logics. In this regard, the perspective of multiple institutional logics could be useful in analysing the interplay between such multiple institutional logics. Thus, the thesis draws upon this perspective to explore which institutional logics are enacted and how they interact during the institutional process of producing social media texts about older people. This may contribute to an improved understanding of how certain social media representations of older people are generated within given institutional contexts.

In summary, this thesis adopts Hjarvard's (2008) conceptual understanding of media logic, which determines the ways in which the media allocates material and symbolic resources, as well as the use of rules (e.g., codes of good practice, rules of procedure, norms). It also uses the perspective of multiple institutional logics to analyse the production processes relating to social media content about older people employed by non-individual producers, which is related to social media representations of older people. 


\section{Chapter 4: Methods and Materials}

This chapter describes the data collection, materials and analyses. It also presents methodological reflections and ethical considerations of importance to the thesis. Table 1 gives a summary of the empirical settings.

TABLE 1. Summary of the empirical settings

\begin{tabular}{|c|c|c|c|c|}
\hline & Article 1 & Article 2 & Article 3 & Article 4 \\
\hline Aim & \multicolumn{4}{|c|}{$\begin{array}{l}\text { This thesis aims to increase our knowledge of social media } \\
\text { representations of older people and improve our understanding of } \\
\text { ageism in the media. }\end{array}$} \\
\hline $\begin{array}{l}\text { Overall } \\
\text { objective }\end{array}$ & \multicolumn{4}{|c|}{$\begin{array}{l}\text { The objective is to examine social media representations of older } \\
\text { people generated by local authorities and media companies, with a } \\
\text { particular focus on exploring how older people are represented in } \\
\text { social media and how social media content about older people is } \\
\text { produced. }\end{array}$} \\
\hline Material & $\begin{array}{l}1,000 \text { social } \\
\text { media images }\end{array}$ & $\begin{array}{l}\text { Interview } \\
\text { transcripts }\end{array}$ & $\begin{array}{l}\text { Written and } \\
\text { spoken text } \\
\text { from a social- } \\
\text { media-based } \\
\text { reality show }\end{array}$ & $\begin{array}{l}188 \text { social } \\
\text { media } \\
\text { hashtags, view } \\
\text { frequency, } \\
\text { comment } \\
\text { frequency }\end{array}$ \\
\hline Analysis & $\begin{array}{l}\text { Content } \\
\text { analysis }\end{array}$ & $\begin{array}{l}\text { Thematic } \\
\text { analysis }\end{array}$ & $\begin{array}{l}\text { Thematic } \\
\text { analysis }\end{array}$ & $\begin{array}{l}\text { Thematic } \\
\text { analysis }\end{array}$ \\
\hline
\end{tabular}

\section{Data collection}

This section presents a description of the data collection, including the contexts from which the data was collected and how it was collected. The thesis is a two-part study that examines social media representations of older people generated by either local authorities or media companies. The first part of the study (including Articles 1 and 2) was performed in the setting of Swedish local authorities; the second part (including Articles 3 and 4) was conducted in the setting of Chinese media companies. The study settings move beyond a focus on Western Anglophone media representations of older people and hopefully lead to new insights into the ways in which older people are represented in these given contexts. It is suggested that readers of this thesis keep in 
mind the contexts from which the data was collected and how the knowledge was generated. Data collection methods are specified in the following.

\section{Swedish local authorities}

The first part of the study focuses on a Swedish municipality: The Municipality of R. The local authorities within this municipality are a particular study setting for this research on social media representations of older people.

Firstly, the municipality is one of the largest in Sweden, with about 150,000 residents in 2019. Similar to other municipalities, the Municipality of R (as an administrative body) is the largest employer in this region, and its largest sector is the health and social care sector. The municipality (including its joint local authorities) is responsible for public facilities and service provision (e.g., housing, roads, water supply and wastewater processing, schools and social care). Most people who are resident in the municipal nursing homes have multiple illnesses and disabilities, as well as extensive care needs (National Board of Health and Welfare, 2019).

Secondly, the Municipality of $\mathrm{R}$ is at the forefront of social media use and the development of social media policy, compared to many other municipalities in Sweden, which have just started to use social media and develop social media policy or guidelines locally. In terms of social media policy or guidelines, the municipality has formulated the publication: A Source of Inspiration for Equal Communication and Social Media Handbook. In practice, the social media platforms used by this municipality (including joint authorities) are Facebook, Instagram, LinkedIn, Twitter and blogs.

Lastly, the municipality (as the administration) is one of the central actors stimulating regional growth in terms of visualization. It is claimed to be one of the actors building up the most attractive innovation environment of visualization in Europe (Visual Sweden, n.d.). The municipality published its policy of image use: Image Language of $R$ Municipality, which calls for local authorities to arouse the target group's curiosity and make the highlighted areas more accessible and attractive to citizens.

Overall, this municipality (including local authorities) is a distinctive context that is worthy of study and may allow new insights into social 
media representations of older people generated by local authorities (as relatively new social media adopters). The knowledge generated from this study setting can provide a valuable basis for the assessment and improvement of local authorities' production of social media photos of older people. This, in turn, can promote more diverse and thoughtful representations of older people in authority-managed social media. The municipality under question is a region with which I am familiar. Thus, it was easy for me to gain access to the data and the context in which the data was generated. It was also possible for me to increase the social impact of this research by informing municipal policy and practice in terms of how to tackle ageism in authority-managed social media.

Two types of data were collected from the Swedish local authorities in order to address the objectives of the empirical studies. Firstly, visual images posted on authority-managed social media sites were collected in order to explore the ways in which older people were visually represented (Article 1); secondly, interviews with communication officers were conducted in order to collect data about the production processes relating to social media photos of older people within the municipality's local authorities (Article 2).

Specifically, in 2018, visual images were collected from the Facebook pages managed by the municipality's local authorities, as Facebook was the most popular social media platform used by these authorities. According to a source within the municipality, 33 local authorities had created publicly accessible Facebook pages by the end of 2018. A set of inclusion and exclusion criteria were established for the process of data collection, including: (1) Facebook posts including visual images of people published in 2018 were chosen, as the thesis requires the most recent data and aims to generate timely recommendations for municipal policy and practice; (2) duplicated and blurred photos, as well as infographics, were screened out, given the feasibility of the coding process; (3) any sets of photos of the same scene taken from multiple perspectives were assembled into one composite image, since viewers often cognitively perceive them as one scene through the visual sense. Complying with these criteria, a data corpus of 1,000 images was created.

Interviews with communication officers were conducted in order to generate data about the production processes relating to social media photos of older people in the context of the same Swedish municipality. 
Interview invitations were firstly sent to 13 communication officers who managed the local authorities' social media pages so as to obtain insights from a diversity of authorities that actively use social media. About one-third of these invitees declined the invitation due to nonavailability for interviews; eight communication officers accepted the invitation and participated in the study. Despite the fact that the five rejections may perhaps have led to the loss of some valuable insights, a variety of authority perspectives was reasonably achieved because the involved participants worked in a selection of commonly representative work areas within the municipality (i.e., public information, education, social care, culture and leisure).

In terms of the implications of a small sample size in interview-based studies, Vasileiou et al. (2018) argued that a small sample size is often seen as a study limitation, because it seems to threaten the validity of the results (referring to the credibility of the research findings). Morse et al. (2002) noted that one of the methodological strategies adopted by qualitative researchers to ensure the credibility of their findings is to establish a sample of study participants who best represent, or have key knowledge about, the research topic. This may result in sufficient data being obtained to account for all aspects of the phenomenon. Additionally, Mason (2002) suggested achieving diversity within the sample, which may enable qualitative researchers to address research questions from a variety of angles. Reflecting upon the implications of the sample size for the present thesis, the sample of eight study participants may still preserve internal validity of the findings, even though a larger sample would have been more informative. This is because the data collection resulted in a large amount of useful information being obtained from participants, which was sufficient to discuss variations among their experiences. Since there are few studies to date that have investigated the production processes relating to social media photos of older people within local authorities, an explorative study with eight participants may still be able to generate new knowledge about the ways in which communication officers produce social media photos of older people.

In terms of the data collection process, semi-structured, in-depth interviews were performed with these participants, which took place at their workplaces, during the period from June to October 2019. The overarching focus of these interviews was on the production of social 
media photos of people of different ages, with a particular focus on older people. An interview guide (for details, see Appendix 1) was used. Audio recordings were made of the interviews with the consent of study participants (for the information letter and consent form, see Appendix 2 ). The interviews lasted 40-70 minutes. Interview recordings were transcribed verbatim.

\section{Chinese media companies}

The other section of the research was performed in the setting of Chinese media companies (including an entertainment company called Tencent Video and a technology company called Sina Weibo, which offers a microblogging service). Two types of social media data were collected from these companies in order to examine social media representations of older people in particular contexts. Firstly, spoken and written text about older people with dementia was collected from Forget Me Not Café, a social-media-based reality show produced by Tencent Video (Article 3); secondly, social media hashtags about older people during the outbreak of COVID-19 were collected from Sina Weibo, which is equivalent to Twitter (Article 4). The following paragraphs specify the data collection contexts and processes.

Tencent Video is an entertainment company which is a particular setting to examine novel social media representations of older people given the following concerns. Firstly, Tencent Video is the most popular online video platform in China (often seen as similar to Netflix). As Fung (2019) argued, Tencent Video is a market leader in terms of advertising revenues, membership fees, daily active users, registered numbers and app downloads, compared with other China-based online video platforms. For example, it had over 106 million subscribers as of December 2019, which indicates the company's potentially powerful role in generating and circulating meaning within Chinese society. Secondly, Tencent Video is one of the top China-based online television production companies, whose content strategy is to create original content and programmes. As shown on its platform, Tencent Video has produced and delivered a diversity of online television programmes (including dramas and reality shows) to its audience in mainland China. Tencent Video is often seen as a market leader in producing novel media genres that merge social media with other types of television programming (e.g., reality television). 
Research on the social media representations of older people generated by this media company may generate new insights into how older people are represented in novel social media formats. In 2019, Tencent Video produced the first and most popular social-media-based reality show focusing on older people with dementia, Forget Me Not Café. According to the reality-show director, this show aims to improve the understanding of dementia and reduce its stigma (Cai, 2019). It used a documentary filming approach and portrayed five older people diagnosed with dementia performing as restaurant servers. Similar reality shows about dementia can also be seen in South Korea and the United Kingdom.

The data collected from this reality show consists of written and spoken text about older people with dementia. In terms of the data collection process, all of the full episodes were watched and re-watched in order to achieve familiarity with the reality-show content. Special attention was paid to the utterances about dementia and older people (or old age, or later life). All written or spoken content including the phrases "dementia," "(mild) cognitive impairment," "people living with dementia" or "people living with cognitive impairment" was noted and the audio content was transcribed verbatim into text, together with the on-screen text. A transcript of 5,371 Chinese characters was produced. Several keywords were used to create inclusion criteria for selecting those parts of the transcripts that are explicitly relevant to older people and later life. The keywords are: "older people," "older parent," "grandparent," "older women," "older men," "old age," "being old," and "... (65+) years old." As a result, a data corpus of 4,316 characters was created as the material for data analysis.

Sina Weibo is a technology company that offers microblogging services (in the form of a mobile app and website). It can be a particular setting for examining dominant social media representations of older people for the following reasons. Firstly, Sina Weibo is the most influential microblogging platform globally, with over 523 million active monthly users as of 2020 Quarter 2. In this sense, Weibo can be seen as one of the most vital sources of information about older people for many of those in Chinese society. Sina Weibo (often seen as a Chinese version of Twitter) can encourage user relationships to share, disseminate and receive information. The public nature of Weibo plays an important role in generating rich and publicly available data, for 
instance, during the outbreak of COVID-19 in China. Secondly, Sina Weibo demonstrates a social feature because Weibo users can seek more comprehensive content on trending topics. "Trending Topics" (equivalent to Twitter hashtags) on Weibo is a list of currently popular topics based partly on user participation and partly on the preferences of Weibo's management staff. Specifically, users can actively participate in popularizing certain topics by means of click-throughs and posts; meanwhile, the list of "Trending Topics" on Weibo is subject to the control of this media company. Thus, Weibo can be a study setting that is worth examining in order to identify the dominant social media representations of older people generated by this technology company during a given period.

Weibo topics were initially collected by Xi (the first author of Article 4) during a two-month period between 1 March 2020, and 30 April 2020. A set of Chinese keywords was employed to search the Weibo Topics about older people, making use of the Weibo search engine: "older people," "old-aged people," "grandmother," "grandfather," "old grandmother," "old grandfather," "old woman," "old man," and "60+ years old." The numbers of "views" and "comments," as well as the creation date of each topic, were also collected. Xi and I went over the search results together and manually sorted out the topics about COVID-19 in China during the period from 20 January to 28 April 2020, resulting in 241 topics. The reason for choosing this time period is that it covers three pivotal stages of the COVID-19 epidemic (for the justification of these three stages, see The State Council Information Office of the People's Republic of China, 2020): (1) the initial period of the COVID-19 outbreak (from 20 January to 20 February); (2) the turnover period (from 21 February to $17 \mathrm{March}$ ); and (3) the post-peak period (from 18 March to 28 April). Identical topics were merged, resulting in a data corpus of 188 unique topics for analysis.

\section{Materials}

The research used materials in contemporary popular cultural forms. Social media data (with visual, textual and auditory properties) were the research materials used in Articles 1, 3 and 4. Specifically, in Article 1, a data corpus of 1,000 social media images of people of all ages was used in the analysis, comprising the Facebook images posted by local authorities. In Article 3, a data corpus of spoken and written text about 
older people with dementia was used in the analysis, including 4,316 Chinese characters. In Article 4, 188 Weibo Topics, as well as the numbers of views and comments for each topic, were used in the analysis. This data is relevant and appropriate to the aim of the thesis and the specific objectives of each empirical study. These types of social media data are derived from relatively novel formats used by non-individual actors on social media. Additionally, they have not been sufficiently examined in the previous research on media representations of older people.

Given that technological convergence has brought about compressions of visuals, texts and videos, as well as their rapid expansion across digital media platforms (Lawson-Borders, 2006), the analyses of these data may perhaps generate a broader understanding of the ways in which older people are represented in today's social media space. Moreover, interview transcripts were used to address the study objective of exploring the production processes relating to social media photos of older people used by local authorities (Article 2). The transcripts of interviews with communication officers include 36 pages of narrative data in English. These transcripts reveal the scenes behind the posted photos of older people and provide data about what purpose they may serve, what has been selected and excluded, and how they fit into the producers' agenda.

\section{Analyses}

Content analysis and thematic analysis were used to identify the ways in which older people were represented on social media. The following reasons guided the choice of analyses.

\section{Content analysis}

A quantitative content analysis of visual images (Rose, 2016) was performed in order to identify visual representations of older people in local-authority-managed social media (Article 1). There are three major reasons why I chose to perform a quantitative content analysis of these visual images.

Firstly, visual content analysis is an observational method that is often used to examine the ways in which things and people are represented in visual images in compositional modality (Bell, 2001). It helps us to understand the symbolic qualities of texts, as "elements of a 
text always refer to the wider cultural context of which they are a part" (Rose, 2016: 87). In this regard, it fits into the constructionist perspective of considering media representations as symbolic work. It can be used to achieve the study's purpose, which is to identify the ways in which older people (or other age groups) are visually represented in social media images.

Secondly, content analysis can provide clear guidelines for analysing a handful of images consistently and systematically. Content analysis is featured by its methodological explicitness, which requires analysts to rigorously follow a number of rules and procedures during the analysis of images (Rose, 2016). Thus, content analysis is a good option for systematically and consistently analysing the 1,000 visual images collected for this study.

Lastly, content analysis allows the discovery of patterns that are not visible to researchers dealing with hundreds of images. In this sense, it can quantify qualitative data, which might help to convince policymakers and practitioners about how to improve their signifying practices in those analytical aspects.

In terms of the limitations of visual content analysis, Leiss et al. (1997) argued that it risks being limited by its analytical focus on the surface level of visual messages. Additionally, Rose (2016) argued that content analysis is much concerned with the image itself and does not deal with the context in which the meanings of images are created. To address these issues, I discussed several of the recurring objects, activities and contexts that are embedded in the social media images of older people. I also performed a production study investigating the production processes relating to social media images of older people used by local authorities, which follows the content analysis.

\section{Thematic analysis}

Thematic analysis is a method that can be used to systematically identify, analyse and report patterns of meaning across a dataset (Braun $\&$ Clarke, 2006). It was chosen for the data analysis in Articles 2, 3 and 4 for the following two reasons.

Firstly, the focus of the research and the sampled qualitative data all suited thematic analysis. Thematic analysis can be used to identify the patterns of meaning (i.e., themes) generated by media texts about older people, as well as media producers' experiences and views of social 
media content production concerning older people in a series of interview transcripts.

Secondly, thematic analysis provides an accessible and theoretically flexible approach to making sense of collective or shared meanings and experiences (Braun \& Clarke, 2012). Thematic analysis can be used in various forms to address different types of research questions. Specifically, inductive thematic analysis can address the exploratory research questions as to how older people were represented during a given period on a particular social media platform (e.g., in Article 4) by giving a clear voice to the data, as the inductive approach can be particularly useful when exploring new areas. Additionally, abductive thematic analysis can be useful in seeking an explanation among many alternatives to explain a surprising phenomenon (e.g., dominant photos casting light on the bright side of later life, in Article 2). It can enable the constructionist orientation in the theoretical framework and give voice to experience and meaning in the data. In this sense, an abductive approach enabled me to draw upon the perspective of multiple institutional logics, and to code the data using theoretical constructs on the basis of study participants' experiences and accounts. Thus, a combination of inductive and deductive thematic analysis is indicated in the thesis.

Thematic analysis was used in the thesis, following a series of procedures (Braun \& Clarke, 2006). ATLAS.ti, a qualitative data analysis software package, was used to systematically code and analyse the data across the data sets. Reports of themes produced by the software served as the basis for an in-depth analysis of the data extracts within themes. All the article authors agreed on the selection of extracts to illustrate the essence of the arguments made in the articles.

The relationship between the data analyses performed in the studies is that they were all manifest in the process where I as a researcher actively engaged with the data, which is underpinned by the ontological position of constructionism. As argued by Braun and Clarke (n.d.), coding is seen as a process which inevitably bears the mark of the researcher(s). In their accounts of reflective thematic analysis, they argued that themes are analytical outputs created from codes and through the researcher's active engagement with the data (Braun \& Clarke, n.d.). This thesis contends that researchers are part of the meaning production. The following specifies several ways in which I 
engaged with my own data. In the content analysis of social media images (Article 1), open coding was performed for certain analytical aspects (e.g., "Activity," "Roles in Activity" and "Objects"), whereby I generated codes based on what I saw as salient in the images. There was no single 'accurate' way to code the data relating to these aspects. So, a high degree of inter-coder reliability was not aimed for, while a greater extent of intra-coder reliability was expected in order to achieve better consistency in the data coding. In the thematic analysis of interview transcripts (Article 2), I engaged with the literature of multiple institutional logics that is relevant to my analysis during the interpretative stages of grouping codes and defining the groups. In so doing, I expected not to narrow the analytical aspects at the greater cost of losing other potentially important aspects during the process of data coding. In the thematic analysis of social media hashtags (Article 4), the active and reflective process of coding is manifest in the use of coding memos within the team that recorded the changes in codes, the definition of codes (in Chinese and English) and the coders, as well as other types of notes.

\section{Methodological reflections}

The following presents methodological reflections on my own positionality. A large body of research has found that older people are dominantly represented as a vulnerable, disempowered and homogeneous group, which leads to ageism (see Levy et al., 2014; Makita et al., 2019; Soto-Perez-de-Celis, 2020). So, I expected that ageism would manifest itself as negative media representations of older people. Yet, I experienced dissonance between my pre-existing expectations and my own data when I noticed that older people were often represented in an overly positive light. When encountering this contrast, I started questioning the meaning of so-called positive representations of older people in the media, who produces it and how it serves to further the agenda of media producers. In so doing, I problematised these "positive" representations of older people, which echo successful ageing or third-age discourses. This generated new understandings of ageism in the media.

Moreover, my cultural background was simultaneously a challenge and an advantage when performing data collection and analysis in the Swedish local-authority context. For instance, I might not be able to 
fully make sense of the participants' accounts of their work practices, but I might also discover ideas or phenomena that are often taken for granted in Swedish culture. I started researching media representations of older people when I was young, at 25 years old, and lacked knowledge about old age as well as real-life contacts with people of an advanced age. Thus, I might also hold certain stereotypes of older people, as age stereotypes are internalized from the culture at a young age. A profound level of self-awareness about the influences of my positionality was required. Meetings and discussions within the EuroAgeism network ${ }^{5}$ improved my ability to be reflective about the implications of my research practices for the data analysis and interpretative stages, challenging stereotypical perceptions of older people, as well as developing a connection between the studied phenomenon and myself (e.g., ageism concerns people of all ages). Nevertheless, I acknowledge that the self-awareness of such influences on my research is not exhaustive because some influences are not easily identified, and I had not fully articulated them at the time of my work. Reflexivity can be further improved when distancing and detaching oneself from the research.

\section{Ethical considerations}

Ethical approval was not required for this research. The research does not involve the processing of special categories of personal data or personal data relating to criminal convictions and offences.

Publicly available data from social media platforms was used in the research, including Facebook, Tencent Video and Sina Weibo. According to the terms and conditions of these platforms, the data they host is reasonably expected to be observed by everyone and intended to reach as wide an audience as possible. The data is also claimed as public information that can be accessed by anyone using the platforms. For example, Facebook claims in its Terms of Service that Facebook pages and public groups are public spaces where anyone who can see the page or group can see the posts or comments; additionally, the data in these public spaces can be seen, accessed, reshared or downloaded through

\footnotetext{
${ }^{5}$ EuroAgeism is a multi-disciplinary, inter-sectorial, international research, training and supervision programme on ageism. It aims to bring together science and policy by creating an opportunity for a true dialogue in the field via the pursuit of 15 research projects. This research work is one of the projects that aim to address ageism in relation to access to goods and services.
} 
and by third parties (Facebook, n.d.). As suggested in the service terms of Tencent Video and Sina Weibo, the reality show and Weibo Topics are public information that can be accessed by anyone (including nonplatform-users).

The social media data collected from Tencent Video and Sina Weibo does not include any identifiable personal data, while the visual data collected from the Facebook pages managed by local authorities does contain identifiable personal data. With a focus on the processing of visual images, Wiles et al. (2008) argued that researchers should comply with the guiding principles of ethical research (i.e., consent, anonymity and confidentiality) in practice. In the present research, I sent an information letter about my research to the communication officer at the municipality through a contact person of the municipality at the university. I also requested consent from the officer, via emails and on-site meetings, concerning the use of visual images (including data collection, data analysis, visual presentation and the reproduction of certain images) posted on local-authority-managed Facebook pages. This consent was received and stored as an email conversation. I was informed by communication officers at the municipality that the people in the posted visual images had already given written consent to the municipality which allows the municipality to present their photos on social media (and/or other mass media). While the identifiable persons in the posted visual images can be seen as having given consent that accepts that third parties may access their photos, this research has retained the confidentiality and anonymity of the people who appear in the visual images from the ethical research perspective. Specifically, I used Photoshop to blur any identifiable information about the people in the visual images. These images have been stored in my personal OneDrive space, which is administrated by Linköping University.

As another critical component of my research data, audio recordings were made of the interviews with the consent of study participants. These lasted 40-70 minutes. Interview recordings were transcribed verbatim into 36-page narrative data using Word documents. The transcripts and audio recordings have been stored in my personal OneDrive space administrated by Linköping University. Additionally, the completed and signed forms have been stored in the same online space. Only the doctoral researcher and supervisors have access to these materials. According to the university's data protection policy 
(Linköping University, 2018), research data needs to be stored for 10 years after a project begins, which means that the data used in my research for this thesis will be deleted in August 2028. 


\section{Chapter 5: Summary of Results}

\section{Article 1}

(Non-)Stereotypical representations of older people in Swedish authority-managed social media ${ }^{6}$

This study aimed to examine the ways in which Swedish local authorities visually portray older people in their use of Facebook compared with other age groups. A visual content analysis of 1,000 Facebook posts posted by local authorities was performed, using ten analytical aspects to describe and interpret the signs, activities and contexts associated with five age groups (infants, children, adolescents, adults and older people). This study identified the repeated signs, activities and contexts that served to represent older people (mainly those in nursing homes) as remaining socially engaged and moderately physically capable. This homogenised representation of older people was established through dominant depictions of sociable third agers and reinforced by marginalizing the portrayals of people in very old age. Specifically, while senior care recipients were mostly portrayed as employing good self-management, but with caregivers shown to the side, their walking aids were often shown at the edge of the photo frame, thus becoming unnoticeable and failing to communicate the care needs of these people in this given context. This representation of older people on the local-authority Facebook pages mostly resonates with the positive stereotype of older people as "golden agers" and counteracts the prevalent negative stereotypes of older people as being out of touch and dependent. When compared with other age groups, older people were represented as inferior to the young in terms of physical and technological competence, based on the connotations of the signs. Additionally, the study found that the representations of older people on the Facebook pages of local authorities appeared to be not very diverse.

\footnotetext{
${ }^{6}$ Cite this article: Xu, W. (2020). (Non-)Stereotypical representations of older people in Swedish authority-managed social media. Ageing \& Society. Advance online publication. https://doi.org/10.1017/S0144686X20001075
} 


\section{Article 2}

Communication officers in local authorities meeting social media: On the production of social media photos of older adults

This study aimed to investigate the production process for social media photos of older people within local authorities from a perspective of multiple institutional logics. An abductive thematic analysis was performed using semi-structured interviews with communication officers in a Swedish municipality. The study found that two institutional logics were enacted in the production processes relating to social media photos of older people within local authorities, where certain core values of bureaucracy and elements of social media logic were manifest in work practice, activities and motives within the local authorities. Social media logic appeared to function more in alliance with bureaucratic logic rather than contesting with each other in the production of social media photos. This mostly led to a visual representation of sociable, active and healthy older people who receive care services from the municipality (often termed as a third-age representation). The analysis illustrates that the stereotypical third-age representation was a result of communication officers striving to create a good image of the municipality and its services, while following municipal policy and EU law on data protection. This meant that they sought photos through particular sources, adjusted to and developed photographic standards of good photos, and endeavoured to promote social media engagement with the photos. This study argues that social media logic seems to play a critical role in promoting the representation of older people as maintaining engagement and independence in localauthority-managed social media, indicating its power to extend the social media discourse beyond the institutional boundaries of social media. 


\section{Article 3}

The stigma of dementia and the media: An analysis of reality shows about older people with dementia running a pop-up restaurant

This study aimed to explore how reality-show participants talked (or wrote) about older people with dementia, in a social media-based reality show which portrayed five people with dementia (aged 65 and older) running a restaurant and was intended to reduce the stigma of dementia. A thematic analysis was conducted on the written and spoken content concerning dementia in older people. The study found that the older people with dementia (as reality-show participants) demonstrated an ability to live with their condition and still contribute to their families and society. These participants were portrayed as pursuing personal goals of sustaining a happy, meaningful and sociable life, as well as taking actions to positively influence their personal circumstances. The study also found that the reality-show participants expressed social expectations towards people with dementia and family carers: for example, they expected people with dementia to actively work towards achieving positive ageing outcomes and expected adult children to provide dementia care. The analysis indicates that a diversity of realityshow participants expressed certain views (e.g., that dementia is a normal part of the ageing process) that echoed some social stereotypes of ageing (a component of ageism). This study argues that the reality show in question might perhaps help to reduce the stigma of dementia and empower older people living with dementia, but it might also tend to stress the responsibility of family carers to provide care and shift the responsibility for managing dementia-related challenges to the older people who are living with dementia. Given that social-media-based reality shows often pursue the achievement of "authenticity" and consider it a selling point in the context of intense competition for both advertisers and viewers in media markets, this study argues that reality shows could be stronger in presenting the personal narratives of people living with dementia, could avoid portraying older people with dementia as "perfect models" and could take the chance to spark a discussion about improving public support for people with dementia. 


\section{Article 4}

A thematic analysis of Weibo topics (Chinese Twitter hashtags) regarding older people during the COVID-19 outbreak ${ }^{7}$

This study aimed to identify representations of older people in Weibo Topics (equivalent to Twitter hashtags) and social media users' responses to those topics on the platform during the COVID-19 outbreak. An inductive thematic analysis was performed to organize Weibo Topics into themes. This study found that "Older people contributing to the community," "Older patients in hospital" and "Older people as a vulnerable group" were the most dominant themes, followed by "Care recipients," "Older people caring for the young" and "Public health rule breakers and followers." The study also found that the theme "Older people caring for the young" became significantly prominent during the first two stages of the sampled period. Based on "average view frequency" and "average comment frequency" by social media users, the popularity of each theme was identified. Specifically, this study found that the theme "Public health rule breakers and followers" had the highest average number of views per topic, while the theme "Contributing to the community" received the most public comments per topic. The study argues that older people were prevalently represented as being warm, competent and contributing to family and community on Weibo during the delineated period. It also argues that the engagement of social media users indicates signs of interest in intergenerational solidarity during that period in mainland China.

\footnotetext{
${ }^{7}$ Cite this article: Xi, W., Xu, W., Zhang, X. \& Ayalon, L. (2020). A thematic analysis of Weibo topics (Chinese Twitter hashtags) regarding older people during the COVID-19 outbreak. The Journals of Gerontology, Series B: Psychological Sciences and Social Sciences. Advance online publication. https://doi.org/10.1093/geronb/gbaa148
} 


\section{Chapter 6: Discussion}

Based on the findings of the research, this chapter presents a discussion on the representation process concerning older people, the role that social media logic plays in generating representations of older people, and the way in which media producers (e.g., local authorities, media companies) can mitigate ageism in the media.

Social media representations of older people that lead to ageism

The results of this research serve to increase our knowledge about social media representations of older people and improve our understanding of ageism in the media. Drawing upon the constructionistrepresentation perspective and the conceptual understanding of ageism, the following discusses the representation process concerning older people.

Drawing upon the constructionist perspective, media representation is approached as a process through which meaning is created and reshaped. As indicated in Article 1 of this thesis, the selection and exclusion of meanings about older people and later life were achieved through the configuration of codes relating to various properties (visual, textual, auditory and digital), when older people were represented as being associated with certain signs, activities and contexts in the media. This signifying process applies to the representation of both older people and other age groups. For example, the codes "coffee breaks" and "foot bathing" were mostly used to configure visual images of older people, while the codes "physical exercising" and "vocational training" were predominantly linked to visual images of teenagers. The codes used in the representation process may carry age-related attributes and sociocultural meanings in the given context, which indicates signs of age stereotyping. As identified in previous studies examining the image of older people in advertising, older characters were mostly portrayed in positively stereotyped roles, such as the golden ager or the perfect grandparent in US commercials (see D. W. Miller et al., 2004; P. N. Miller et al., 1999). As these representations of older people were consistent with the positive stereotypes of older people in Western societies, they were labelled as "positive" representations of older people. As illustrated in Articles 1 and 3 of this thesis, the 
representation of older people on social media was found to be in line with these positive stereotypes (e.g., the "golden ager" and "perfect grandparent"). Specifically, the analyses showed that the social media content primarily focused on the bright side of later life and represented older people (including those in supportive care) as being happy, socially active and vital, relatively healthy, and taking actions to positively influence their personal circumstances. I argue that the meanings generated by such social media representations emphasize that older people live as well as the lifestyle that they pursue and lead. Since these meanings echo the third-age rhetoric, I termed these representations stereotypical third-age representations in this thesis. Swift and Steeden (2020) argued that stereotypical representations of older people in the media may homogenize the older population and excessively exaggerate the differences between older people and others. In this sense, I argue that the stereotypical third-age representation may perpetuate age stereotypes and lead to ageism, given the media's role in influencing people's perceptions and attitudes towards older people and ageing.

Relations of power are inscribed and reproduced by media representations from the constructionist point of view. As indicated by the results of this research, the power implicated in representations of older people has been twofold. As argued by previous studies, age strata are coupled with corresponding unproblematized norms. For instance, Johansson (2010) argued that adolescents are "human becomings" who will be taking over and succeeding in society; Uprichard (2008) argued that these "becomings" are active agents in the present and future, who decide what kinds of adults they will become. Ranzijn (2004) found that older employees were portrayed as "has-beens" in the workplace, with little new knowledge and few aspirations for the future. When it comes to the context of municipal life, I found, with the use of a life-course perspective (Närvänen, 2004), that older people were represented in a less diversified manner and in fewer active roles than younger age groups. This suggests asymmetrical power relations among age groups in the municipal context, where older people have insufficient cultural capital (e.g., lifestyles, skills and habitus related to art or cultural tastes) compared to their younger counterparts. In this regard, such social media representations of older people reproduce the relations of age power in that given context, which may suggest a relatively low level 
of municipal investment in supporting older people to maintain their status as active actors, and thus lead to ageism.

The other power perspective is concerned with how older people should live during later life. Krekula et al. (2018: 41) argued that this type of power, with an emphasis on normativity in relation to temporality, "is practised through notions of how life ought to be lived and through norms of what is considered a natural consequence and time for different phases in life." In the present research, I found that the data of inquiry demonstrated several social expectations of older people living with dementia in the reality show discourse, as well as older people during the COVID-19 outbreak, which indicated the exercising of such power. Specifically, the analysis suggests that older people were expected to maintain their physical and mental health, pursue personal life goals and to have an active lifestyle, as well as contributing to their family and community. In this regard, such representations of older people embody neo-liberal tenets, which promote individual effort and responsibility for managing challenges in later life. I argue that this social practice of power may contribute to normalising such expectations towards older people, irrespective of whether they wish to live up to them, which may lead to ageism.

The present research acknowledges the complexity of social media representations of older people, which causes difficulties in describing the representations by using binary oppositions (e.g., positive/negative, accurate/unrealistic). There has been a body of earlier studies identifying unrealistic, negative and offensive representations of older people (as being frail, vulnerable and dependent) in the given contexts, which were labelled as a manifestation of ageism in the media (see Atkins et al., 1990; Lundgren \& Ljuslinder, 2012; Robinson \& Popovich, 2003). It is noteworthy that the representations of older people cast light on the ideals of agelessness, good health and independence in later life, which have become more prominent in today's media space. The third-age rhetoric has become increasingly recognized in various media contexts. For instance, Loos and Ivan (2018) found that print and television representations of older people moved from "negative" images to more "positive" depictions during the last decade of the twentieth century, based on a review of empirical studies conducted since 1950 in Europe and North America. Moreover, representations of older people as being in filled with vitality were 
identified in the media managed by contemporary public-sector organizations working for senior citizens (see Carlstedt, 2019; Christensen, 2019; Loos \& Ivan, 2018). These stereotypical third-age representations can be seen as a counter-narrative to the prevalent negative stereotypes of older people (e.g., a homogeneous group who are out of touch and dependent), while they can lead to narrow typecasting and stereotyping of older people as remaining sociable, active and relatively healthy. Additionally, they are still at risk of (re)producing stereotypes of older people, as well as failing to highlight the heterogeneity of the older population.

With a particular focus on the ill-health aspect of older people, I found that older people in supportive care were mostly represented as displaying good self-control and self-management, as well as being well-functioning. The findings of this research also suggest the denial of physical and cognitive decline. For instance, the visual images of nursing-home residents de-visualized or marginalized walking aids in the frames, while the reality-show participants expressed their fears about ageing and dementia. These denials of existing physical or cognitive decline are at risk of overgeneralizing the notions of autonomy and independence in the entire older population. They also indicate the marginalization of possible decline to very old age and specific purposes which do not fully represent the interests of older people. Gilleard and Higgs (2010) argued that the contemporary concentration of infirmity within long-term care makes sense of old age as an undesirable "social imaginary." Additionally, Higgs and Gilleard (2019) connected the social imaginary of the fourth age with the concept of ageism, by looking at the collective imagination about the key corporeal processes of ageing (e.g., becoming less attractive, less healthy and in decline). In this regard, the social media representation of older people in supportive care (as signifying practice) seems to distance them from very old age, which does not help to tackle the notions of fragility, decline and death that are often associated with the fourth age.

\section{Social media logic and the representation of older people}

Altheide and Snow (1979) defined media logic as a form of communication and highlighted the influence of media formats in constructing messages within a particular medium (Altheide \& Snow, 
1979: 10). Additionally, media logic was developed as a concept referring to the organizational, technological and aesthetic determinants of media functioning (Hjarvard, 2008). This concept is associated with the ideas of media content production and media effects. Drawing upon the institutional perspective of the media, the following discusses the role that social media logic plays when non-individual media producers generate representations of older people.

From the perspective of content production, media logic may function as a formatting logic that determines the organization of material resources, the presentation mode and the selection of social experience (Mazzoleni \& Splendore, 2015). As illustrated in the previous chapter, social media logic directed communication officers to selectively design and publish photos showing sociable, active and healthy older people on local-authority-managed social media sites. This finding suggests that social media logic plays a critical role in determining the allocation of material and symbolic resources. Thus, I argue that social media logic can play a critical role in influencing the way in which communication officers produce social media content about older people for local-authority-managed social media sites. From the perspective of media effects, media logic is a key concept within mediatization research examining media-related impacts on other social institutions. Van Dijck and Poell (2013) argued that social media serves as an independent institution that gradually permeates all areas of public life; they also proposed forms of social media logic to which other social institutions are forced to adapt, while also becoming an integrated part of other institutions, given the ways in which many institutional activities are conducted through social media.

The present research found that communication officers performed the institutional activities related to generating social media representations of older people. Specifically, it found that they complied with institutional policy concerning social media use and the procedures of visual image production, adjusted to the photographic standards of good social media photos, and promoted social media engagement with the photos. These findings suggest that social media logic may have a function in determining the representation of older people in local-authority-managed social media, making use of its rules, both formal and informal. In this regard, I argue that the way in which social media logic functions in the production process for social media 
photos of older people within local authorities may stabilize the stereotypical third-age representation, which may lead to institutional ageism.

Palmore (1999: 44) defined institutional ageism as "a policy of an institution or organization that discriminates for or against older people" and exemplified the patterns of institutional ageism in the economy, government, family, housing and healthcare. Dennis and Thomas (2007) described institutional ageism as "established rules, missions, and practices that discriminate against older people or groups based on age." A recent analysis of institutional ageism in global health policy by Lloyd-Sherlock et al. (2016) critically evaluated one of the Sustainable Development Goals (i.e., "by 2030 reduce by one-third premature mortality from non-communicable diseases through prevention and treatment") and argued that this target probably promotes institutional ageism by "discouraging research and data collection, focusing resources on younger people, and exacerbating existing discrimination." Ivan et al. (2020) defined visual ageism as a specific aspect of institutional ageism, referring to media practices of visually underrepresenting or misrepresenting older people in a prejudiced way. Based on the findings of the present research, I argue that institutional ageism may be manifest in the mediatized institutions with an established process of content production that stabilizes stereotypical representations of older people in the media. In this sense, the present research may serve to develop an understanding of institutional ageism in the media.

\section{Mitigating ageism in social media}

This section discusses possible ways in which media producers can mitigate ageism in social media concerning the particular aspect of media representations of older people. Additionally, it proposes policy recommendations for media producers in terms of reducing ageism in social media.

Previous research on ageing and the media has envisioned what may constitute a fair image of older people in the media. For instance, Vickers (2007) argued for greater visibility of older people in the media. Milner et al. (2012) called for accurate and balanced representations of older people in the media. Hannah and Steeden (2020) found that there was a deficiency of balanced representations of older people that mirror 
their actual lived experiences, based on a literature review of existing research about the role and impact of language and stereotypes in framing old age and ageing in Britain. Moreover, Loos and Ivan (2018) advocated for diverse representations of older people in the media with the use of more varied images to challenge the representation of homogeneous older people. These visions of a fair representation of older people in the media are mostly underpinned by the reflectionist perspective of media representation (i.e., the media should reflect the social world). Given that, from a constructionist perspective, media representation is the process by which meaning is produced, the present research rather calls for more thoughtful and reflexive representations of older people in the media, as well as seeking accountability of media producers as a critical way of reducing the representations of older people that may lead to ageism.

The production of social media content addressing older people by non-individual entities must be viewed in the context of digitalization and the use of social media. Digitalization has the power to improve the delivery of services, and ensure transparency, participation and collaboration in the decision-making process (Blanc, 2020). Milakovich (2012) argued that digitalization can have positive impacts in terms of cost reduction, productivity improvement, informationsharing, full-scale citizen participation and realizing a form of decisionmaking that is more open and transparent. It has been argued that social media can offer opportunities for facilitating citizen participation, public trust and transparency. For instance, Luoma-aho and Canel (2020) argued that innovative forms of participation in social media can empower citizens in terms of taking control of institutional communication, including through the forming and reshaping of services and representation. In this respect, the fostering of digitalization and its successful implementation serve as a context for non-individual social media adopters when generating social media representations of older people. The production of social media content concerning older people can be seen as an accountability task for media producers because they offer services to older people and need to protect their rights. As one of the core institutional principles of egovernance, Bovens (2009: 184) defined accountability as the "social relationship in which an actor feels an obligation to explain and to justify his or her conduct to some significant other." Accountability 
undoubtedly has positive attributes associated with greater transparency and fair governance. Additionally, assessing the actual conduct of institutions is highly desirable (Mark Bovens, 2010).

Social media has enabled users to simultaneously create and consume online content about older people, old age and ageing. It has been widely reported that various social media platforms are witnessing a growing number of users of more advanced age. For example, in Sweden, only four percent of older adults aged between 65 and 79 used social media in 2009, growing to 18 percent in 2012, 20 percent in 2014, 31 percent in 2016, and 39 percent in 2018 (Nordicom, 2019). On Facebook, a growing number of older users has been reported in the United Kingdom and the United States (Saul, 2014; Schaffel, 2018; Sweney, 2018). Leist (2013) emphasized that older people's social media use can have positive effects on developing their health-related knowledge and social relationships, as well as their feelings of control and self-efficacy. Apart from the positive effects of social media use on older people's wellbeing, social media also offers the opportunity for older people to share their personal stories and get their voices heard, which can help to shape social media representations of older people. In their study analysing publicly available blogs written in English by older people, Lazar et al. (2017) found that older adult bloggers criticized stereotypical beliefs focusing on the losses associated with ageing and advocated positive aspects of later life (using English), which developed into an online community with anti-ageism interests. In her observational and survey study on the literate activities of an active community of Instagrammers aged from about 53 to over 80, McGrath (2018) found that midlife and older women generated complex, playful and experimental self-representations, which can be seen as counter-stereotypical portrayals of older people.

These studies suggest that older adult users can compete for control over social media representations of older people and later life by sharing their own experiences of becoming and being old. Trentham et al. (2015) argued that social media offers a venue for older people to challenge ageism and influence public policy; additionally, they advocated for the inclusive design of online technology and training workshops that can support older people's participation in social media. Hence, empowering older people's engagement in generating social 
media representations can be expected to become a vital way to reduce ageism in social media.

Moreover, greater accountability in representation is expected to be seen among media producers. Accountability may entail the increased participation of older people and other civil society actors (e.g., viewers' and pensioners' associations) in generating and evaluating social content relating to older people, while also enhancing their communication with citizens. The following proposes key policy recommendations for enhancing the accountability of media producers in terms of reducing the representations of older people that may lead to ageism.

Improving the awareness of ageism and providing training for media professionals. There is a need to raise awareness about ageism among media producers and offer professional training for them in terms of how to reduce ageism in the media. To fulfil this need, media producers can present explicit views tackling ageism in their content and develop a partnership with relevant stakeholders who have specialist knowledge on ageism (e.g., researchers and policymakers). This also resonates with educational interventions proposed by other researchers. For instance, Carrigan and Szmigin (2003) argued for explicit policy and educational interventions to help the British advertising industry to steer clear of offensive representations of older people. Milner et al. (2012) suggested establishing a post-secondary institution that can provide professional training for media professionals on the heterogeneity of the older population and increase the market's knowledge about healthy and active ageing.

Empowering older people to engage in content production. Older people can directly participate in creating social media content agendas, generating online representations of older people, and evaluating posted social media content that is intended to meet their informational needs. In practice, media producers can offer cameras or smartphones to older people to capture their life experiences, request older people to participate in developing local social media policy and photography standards, as well as constructing more complex assessments of the posted photos of older people. Most importantly, media producers need to ensure the inclusion of older people's authentic voices in order to construct the experience of ageing from a first-person perspective. For instance, they need to present more views of older people (especially 
the oldest-old members of society) with respect to their desires, opinions and so forth. They also need to present coherent and personal life stories of older people and highlight the heterogeneity of people in terms of social background, health status, care needs and personal goals. By advocating for the visual communication rights of older people, Ivan et al. (2020) argued that collaborative means can be developed for involving older people in the creation of digital visual content and enhancing older people's power to meaningfully influence their own representations. In this regard, the participation of older people has the potential to strengthen their position within the power structure of representations of older people online.

Developing material and symbolic resources with older people. Since the repeated representations of older people in the media may contribute to stereotype formation, media professionals need to develop material and symbolic resources with older people and try to avoid the repeated use of certain codes that may lead to stereotypical representations of older people in a given context. Moreover, I call for more social media content that captures the real-life conditions of older people in different contexts and situations. 


\section{Chapter 7: Conclusion}

This chapter presents the conclusions and prospects for future research. Conclusions

The overall objective of this thesis was to examine social media representations of older people generated by local authorities and media companies, with a particular focus on exploring how older people are represented in social media and how social media content about older people is produced. The thesis has provided a depiction of social media representations of older people in the given contexts (including localauthority-managed Facebook pages, an online video platform and a microblogging platform), which has served to problematize the stereotypical third-age representation of older people (including those in supportive care). The results of the thesis reveal the complexity and nuance in the representation process and the meanings generated by the representations of older people in social media. More specifically, the thesis illuminates three ways in which the social media representations of older people lead to ageism: (1) the stereotyping of older people through signifying practice; (2) the generation and negotiation of meaning concerning older people and later life among social actors with different power relations; and (3) the use of both formal and informal rules of social media in the context of social media logic permeating into other institutions.

A synthesis of the findings from the four empirical articles indicates a process of establishing the stereotypical third-age representation as a convention for social media, which can be seen as institutional ageism. The synthesis also indicates that this stereotypical third-age representation appears prominent in the different contexts and various types of social media under investigation. Hence, it is necessary to promote knowledge and raise awareness about the risks associated with such representations of older people in the media. This thesis deepens our understanding of the manifestations and origins of ageism in the media and generates evidence-based policy recommendations for media producers to inspire more thoughtful and reflexive media representations of older people. 


\section{Future research}

As some avenues for future research, it would be worth pushing forward the research on ageism in the media in the following respects.

Firstly, since far too little attention has been paid to the intersectionality of age and other social divisions in the representation process, it is essential to examine the representations of older people from an intersectionality perspective. Secondly, further work is needed to improve our understanding of the ways in which other non-individual social media adopters (e.g., recruitment agencies, unions, consumer goods companies) represent older people. Thirdly, there is a need to give more prominence to the algorithms associated with social media platforms, as these platforms are increasingly becoming independent of social media users in terms of the representation of social phenomena. Lastly, audience research can help to improve our knowledge of the effects of social media representations on the well-being of audiences. 


\section{References}

Altheide, D., \& Snow, R. (1979). Media Logic. Sage.

Amaral, I., Santos, S. J., Daniel, F., \& Filipe, F. (2019). (In)visibilities of men and aging in the media: Discourses from Germany and Portugal. In J. Zhou \& G. Salvendy (Eds.), Human Aspects of IT for the Aged Population: Social Media, Games and Assistive Environments (pp. 2032). Springer.

Angus, J., \& Reeve, P. (2006). Ageism: A threat to "aging well" in the 21st century. Journal of Applied Gerontology, 25(2), 137-152.

Asur, S., \& Huberman, B. A. (2010). Predicting the future with social media. 2010 IEEE/WIC/ACM International Conference on Web Intelligence and Intelligent Agent Technology, 492-499.

Atkins, T., Jenkins, M. C., \& Perkins, M. H. (1990). Portrayal of persons in television commercials age 50 and older. Psychology: A Journal of Human Behavior, 27(4), 30-37.

Ayalon, L., \& Tesch-Römer, C. (2018). Introduction to the section: Ageismconcept and origins. In L. Ayalon \& C. Tesch-Römer (Eds.), Contemporary Perspectives on Ageism. International Perspectives on Aging (pp. 1-10). Springer. https://doi.org/10.1007/978-3-319-738208_1

Bai, X. (2014). Images of ageing in society: A literature review. Journal of Population Ageing, 7(3), 231-253.

Bell, J. (1992). In search of a discourse on aging: The elderly on television. The Gerontologist, 32(3), 305-311.

Bell, P. (2001). Content analysis of visual images. In T. Van Leeuwen \& C. Jewitt (Eds.), The Handbook of Visual Analysis (pp. 10-34). Sage.

Blanc, D. Le. (2020). E-participation: A quick overview of recent qualitative trends (No. 163; DESA Working Paper). https://www.un.org/esa/desa/papers/2020/wp163_2020.pdf

Blumer, H. (1969). Symbolic Interactionism. Prentice Hall.

Bonnesen, J. L., \& Burgess, E. O. (2004). Senior moments: The acceptability of an ageist phrase. Journal of Aging Studies, 18(2), 123-142.

Bovens, M. (2009). Public accountability. In F. Ewan, L. Lawrence Jr, \& C. Pollitt (Eds.), The Oxford Handbook of Public Management (pp. 182208). Oxford Handbooks.

Bovens, Mark. (2010). Two concepts of accountability: Accountability as a virtue and as a mechanism. West European Politics, 33(5), 946-967.

Braun, V., \& Clarke, V. (n.d.). Thematic analysis: A reflexive approach. Retrieved

April

2 ,

2021,

from 
https://www.psych.auckland.ac.nz/en/about/thematic-analysis.html

Braun, V., \& Clarke, V. (2006). Using thematic analysis in psychology. Qualitative Research in Psychology, 3(2), 77-101.

Braun, V., \& Clarke, V. (2012). Thematic analysis. In H. Cooper (Ed.), The Handbook of Research Methods in Psychology (pp. 57-71). American Psychological Association.

Bülow, M. H., \& Söderqvist, T. (2014). Successful ageing: A historical overview and critical analysis of a successful concept. Journal of Aging Studies, 31, 139-149.

Butler, R. N. (1975). Why Survive? Being Old in America. Harper \& Row.

Bytheway, W. (1994). Ageism. Open University Press.

Cai, X. (2019). Reality TV Show Aims to Raise Alzheimer's Awareness. https://www.sixthtone.com/news/1003961/reality-tv-show-aims-toraise-alzheimers-awareness\#: :text=Coproduced by streaming service Tencent, according to the show's producers.

Carlstedt, E. (2019). A fun, active and sociable life on display: Nursing home presentations on Instagram. Ageing and Society, 39(9), 2109-2132.

Carr, C. T., \& Hayes, R. A. (2015). Social media: Defining, developing, and divining. Atlantic Journal of Communication, 23(1), 46-65.

Carrigan, M., \& Szmigin, I. (2000). Advertising and older consumers: Image and ageism. Business Ethics: A European Review, 9(1), 42-50.

Carrigan, M., \& Szmigin, I. (2003). Regulating ageism in UK advertising: An industry perspective. Marketing Intelligence \& Planning, 21(4), 198 204.

Centre for Ageing Better. (2020). Doddery but Dear?: Examining AgeRelated Stereotypes. https://www.ageingbetter.org.uk/sites/default/files/2020-03/Doddery-but-dear.pdf

Chen, C.-H. (2015). Advertising representations of older people in the United Kingdom and Taiwan. The International Journal of Aging and Human Development, 80(2), 140-183.

Christensen, C. L. (2019). Visualising old age: Photographs of older people on the website of the DaneAge Association. Nordicom Review, 40(2), 111-127.

Cohen, H. L. (2002). Developing media literacy skills to challenge television's portrayal of older women. Educational Gerontology, 28(7), 599-620.

Dahlgren, P. (1998). Meaning and/vs. information in media studies. Loisir et Société / Society and Leisure, 21(1), 43-62.

Dennis, H., \& Thomas, K. (2007). Ageism in the workplace. Generations, 31(1), 84-89.

Dixon, M. (2019). Representation: Stuart Hall. In Media Theory for A Level: 
The Essential Revision Guide. Routledge.

Duffy, B. E., \& Pooley, J. D. (2017). "Facebook for academics": The convergence of self-branding and social media logic on Academia.edu. Social Media + Society, 3(1), 205630511769652.

Edström, M. (2018). Visibility patterns of gendered ageism in the media buzz: A study of the representation of gender and age over three decades. Feminist Media Studies, 18(1), 77-93.

Enli, G., \& Simonsen, C.-A. (2018). "Social media logic" meets professional norms: Twitter hashtags usage by journalists and politicians. Information, Communication \& Society, 21(8), 1081-1096.

Facebook. (n.d.). Data Policy. Retrieved January 14, 2021, from https://www.facebook.com/about/privacy

Finnemann, N. O. (2011). Mediatization theory and digital media. Communications, 36(1), 67-89.

Fiske, S. T., Cuddy, A. J. C., Glick, P., \& Xu, J. (2002). A model of (often mixed) stereotype content: Competence and warmth respectively follow from perceived status and competition. Journal of Personality and Social Psychology, 82(6), 878-902.

Fung, A. Y. (2019). Fandomization of online video or television in China. Media, Culture \& Society, 41(7), 995-1010.

Gilleard, C, \& Higgs, P. (2011). The third age as a cultural field. In D. Carr \& K. Komp (Eds.), Gerontology in the Era of the Third Age: Implications and Next Steps. (pp. 33-50). Springer.

Gilleard, Chris, \& Higgs, P. (2010). Aging without agency: Theorizing the fourth age. Aging \& Mental Health, 14(2), 121-128.

Gilleard, Chris, \& Higgs, P. (2014). Studying dementia: The relevance of the fourth age. Quality in Ageing and Older Adults, 15(4), 241-243.

Gilleard, Christopher, \& Higgs, P. (2000). Cultures of ageing: Self, citizen and the body. Routledge.

Gorham, B. W. (1999). Stereotypes in the media: So what? Howard Journal of Communications, 10(4), 229-247.

Haim, M., Karlsson, M., Ferrer-Conill, R., Kammer, A., Elgesem, D., \& Sjøvaag, H. (2021). You should read this study! It investigates Scandinavian social media logics †. Digital Journalism, 1-21. https://doi.org/10.1080/21670811.2021.1886861

Hall, S. (1997). Representation: Cultural Representations and Signifying. Sage.

Hepp, A. (2012). Mediatization and the "molding force" of the media. Communications, 37(1), 1-28.

Hermida, A., \& Mellado, C. (2020). Dimensions of social media logics: 
Mapping forms of journalistic norms and practices on Twitter and Instagram. Digital Journalism, 8(7), 864-884. https://doi.org/10.1080/21670811.2020.1805779

Hiemstra, R., Goodman, M., Middlemiss, M. A., Vosco, R., \& Ziegler, N. (1983). How older persons are portrayed in television advertising: Implications for educators. Educational Gerontology, 9(2-3), 111-122.

Higgs, P., \& Gilleard, C. (2015). Rethinking old age: Theorising the fourth age. Macmillan International Higher Education.

Higgs, Paul, \& Gilleard, C. (2019). The ideology of ageism versus the social imaginary of the fourth age: Two differing approaches to the negative contexts of old age. Ageing and Society, 1-14.

Hjarvard, S. (2008). The mediatization of society. Nordicom Review, 29(2), $102-131$.

Hjarvard, S. (2014). Mediatization and cultural and social change: An institutional perspective. In Knut Lundby (Ed.), Mediatization of Communication: Handbooks of Communication Science (pp. 199-226). De Gruyter Mouton.

Hummert, M. L., Garstka, T. A., Shaner, J. L., \& Strahm, S. (1994). Stereotypes of the elderly held by young, middle-aged, and elderly adults. Journal of Gerontology, 49(5), 240-249.

Ivan, L., Loos, E., \& Tudorie, G. (2020). Mitigating visual ageism in digital media: Designing for dynamic diversity to enhance communication rights for senior citizens. Societies, 10(4), 76.

Iversen, T. N., Larsen, L., \& Solem, P. E. (2009). A conceptual analysis of Ageism. Nordic Psychology, 61(3), 4-22.

Jenkins, H. (2004). The cultural logic of media convergence. International Journal of Cultural Studies, 7(1), 33-43.

Jensen, K. B. (2010). Media Convergence: The Three Degrees of Network, Mass and Interpersonal Communication (1st Edn). Routledge.

Jimenez-Sotomayor, M. R., Gomez-Moreno, C., \& Soto-Perez-de-Celis, E. (2020). Coronavirus, ageism, and Twitter: An evaluation of Tweets about older adults and COVID-19. Journal of the American Geriatrics Society, 68(8), 1661-1665.

Johansson, B. (2010). Subjectivities of the child consumer: Beings and becomings. In D. Buckingham \& V. Tingstad (Eds.), Childhood and Consumer Culture (pp. 80-93). Palgrave Macmillan UK.

Kalsnes, B., Larsson, A. O., \& Enli, G. S. (2017). The social media logic of political interaction: Exploring citizens' and politicians' relationship on Facebook and Twitter. First Monday. https://doi.org/10.5210/fm.v22i2.6348

Kenalemang, L. M. (2021). Visual ageism and the subtle sexualisation of older 
celebrities in L'Oréal's advert campaigns: A Multimodal Critical Discourse Analysis. Ageing and Society, 1-18. https://doi.org/10.1017/S0144686X20002019

Kessler, E.-M., Rakoczy, K., \& Staudinger, U. M. (2004). The portrayal of older people in prime time television series: The match with gerontological evidence. Ageing and Society, 24(4), 531-552.

Kite, M. E., Stockdale, G. D., Whitley, B. E., \& Johnson, B. T. (2005). Attitudes toward younger and older adults: An updated meta-analytic review. Journal of Social Issues, 61(2), 241-266.

Klinger, U., \& Svensson, J. (2015). The emergence of network media logic in political communication: A theoretical approach. New Media \& Society, 17(8), 1241-1257.

Krekula, C., Nikander, P., \& Wilińska, M. (2018). Multiple marginalizations based on age: Gendered ageism and beyond. In L. Ayalon \& C. TeschRömer (Eds.), Contemporary Perspectives on Ageism: International Perspectives on Aging (pp. 33-50). Springer.

Kress, G., \& van Leeuwen, T. (2006). Reading Images: The Grammar of Visual Design (2nd Edn.). Routledge.

Kroon, A. C., Van Selm, M., Ter Hoeven, C. L., \& Vliegenthart, R. (2018). Reliable and unproductive? Stereotypes of older employees in corporate and news media. Ageing and Society, 38(1), 166-191.

Krotz, F. (2009). Mediatization: A concept with which to grasp media and societal change. In Knut Lundby (Ed.), Mediatization: Concept, Changes, Consequences (pp. 21-40). Peter Lang.

Kydd, A., Fleming, A., Gardner, S., \& Hafford-Letchfield, T. (2018). Ageism in the third age. In L. Ayalon \& C. Tesch-Römer (Eds.), Contemporary Perspectives on Ageism. International Perspectives on Aging (pp. 115130). Springer.

Kyvik, S., \& Stensaker, B. (2016). Mergers in Norwegian higher education. In R. Pinheiro, L. Geschwind, \& T. Aarrevaara (Eds.), Mergers in Higher Education (pp. 29-42). Springer.

Laslett, P. (1991). A fresh map of life: The emergence of the third age. Harvard University Press.

Lawson-Borders, G. L. (2006). Media Organizations and Convergence: Case Studies of Media Convergence Pioneers. Routledge.

Lazar, A., Diaz, M., Brewer, R., Kim, C., \& Piper, A. M. (2017). Going gray, failure to hire, and the ick factor. Proceedings of the 2017 ACM Conference on Computer Supported Cooperative Work and Social Computing - CSCW' 17, 655-668.

Lee, B., Kim, B.-C., \& Han, S. (2006). The portrayal of older people in television advertisements: A cross-cultural content analysis of the 
United States and South Korea. The International Journal of Aging and Human Development, 63(4), 279-297.

Lee, M. M., Carpenter, B., \& Meyers, L. S. (2007). Representations of older adults in television advertisements. Journal of Aging Studies, 21(1), 2330.

Leiss, W., Kline, S., \& Jhally, S. (1997). Social Communication in Advertising: Persons, Products \& Images of Well-Being (2nd Edn.). Routledge.

Leist, A. K. (2013). Social media use of older adults: A mini-review. Gerontology, 59(4), 378-384.

Levy, B. R., Chung, P. H., Bedford, T., \& Navrazhina, K. (2014). Facebook as a site for negative age stereotypes. The Gerontologist, 54(2), 172-176.

Lien, S.-C., Zhang, Y. B., \& Hummert, M. L. (2009). Older adults in primetime television dramas in Taiwan: Prevalence, portrayal, and communication interaction. Journal of Cross-Cultural Gerontology, 24(4), 355-372.

Linköping University. (2018). Processing Personal Data at Linköping University:

Guidelines. https://insidan.liu.se/dataskyddsforordningen/riktlinjer/1.753514/Riktli njer-for-personuppgiftsbehandling-vid-LiU-english.pdf

Livingstone, S., \& Lunt, P. (2014). Mediatization: An emerging paradigm for media and communication studies. In K. Lundby (Ed.), Mediatization of Communication. Handbooks of Communication Science (21) (pp. 703724). De Gruyter Mouton.

Lloyd-Sherlock, P. G., Ebrahim, S., McKee, M., \& Prince, M. J. (2016). Institutional ageism in global health policy. BMJ, i4514.

Loos, E. (2013). Visual representation of senior citizens: The role of discourse coalitions for identification with images and accessible information delivery. Online Journal of Communication and Media Technologies, Special Issue, 87-100.

Loos, E. (2018). The organizational use of online stock photos: The impact of representing senior citizens as eternally youthful. Human Technology, 14(3), 366-381.

Loos, E., \& Ivan, L. (2018). Visual ageism in the media. In L. Ayalon \& C. Tesch-Römer (Eds.), Contemporary Perspectives on Ageism: International Perspectives on Aging (pp. 163-176). Springer.

Lundgren, A. S., \& Ljuslinder, K. (2012). "The baby-boom is over and the ageing shock awaits": Populist media imagery in news-press representations of population ageing. International Journal of Ageing and Later Life, 6(2), 39-71.

Luoma-aho, V., \& Canel, M. (Eds. . (2020). The Handbook of Public Sector 
Communication. Wiley.

Maines, D. R. (2000). The social construction of meaning. Contemporary Sociology, 29(4), 577-584.

Makita, M., Mas-Bleda, A., Stuart, E., \& Thelwall, M. (2021). Ageing, old age and older adults: A social media analysis of dominant topics and discourses. Ageing and Society, 41(2), 247-272.

Marhánkova, J. H. (2010). Leisure in old age: Disciplinary practices surrounding the discourse of active ageing. International Journal of Ageing and Later Life, 6(1), 5-32.

Marshall, B. L., \& Rahman, M. (2015). Celebrity, ageing and the construction of "third age" identities. International Journal of Cultural Studies, 18(6), $577-593$.

Mason, J. (2002). Linking qualitative and quantitative data analysis. In A. Bryman \& B. Burgess (Eds.), Analyzing Qualitative Data (pp. 103-124). Routledge.

Mazzoleni, G., \& Splendore, S. (2015). Media logic. In Communication. Oxford University Press.

McGrath, L. (2018). Achieving visibility: Midlife and older women's literate practices on Instagram and blogs. Literacy in Composition Studies, 6(2), 94-116.

Meisner, B. A. (2020). Are you OK, boomer? Intensification of ageism and intergenerational tensions on social media amid COVID-19. Leisure Sciences, $43(1-2)$, 56-61. https://doi.org/10.1080/01490400.2020.1773983

Milakovich, M. E. (2012). Digital Governance: New Technologies for Improving Public Service and Participation. Routledge.

Miller, D. W., Leyell, T. S., \& Mazachek, J. (2004). Stereotypes of the elderly in U.S. television commercials from the 1950s to the 1990s. The International Journal of Aging and Human Development, 58(4), 315340.

Miller, P. N., Miller, D. W., McKibbin, E. M., \& Pettys, G. L. (1999). Stereotypes of the elderly in magazine advertisements 1956-1996. The International Journal of Aging and Human Development, 49(4), 319337.

Milner, C., van Norman, K., \& Milner, J. (2012). The media's portrayal of ageing. In J. R. Beard, S. Biggs, D. E. Bloom, L. P. Fried, P. Hogan, A. Kalache, \& S. J. Olshansky (Eds.), Global Population Ageing: Peril or Promise? (pp. 25-28). World Economic Forum.

Morse, J. M., Barrett, M., Mayan, M., Olson, K., \& Spiers, J. (2002). Verification strategies for establishing reliability and validity in qualitative research. International Journal of Qualitative Methods, 1(2), 


\section{$13-22$.}

Närvänen, A.-L. (2004). Age, ageing and the life course. In B.-M. Öberg, A.L. Närvänen, E. Näsman, \& E. Olsson (Eds.), Changing Worlds and the Ageing Subject: Dimensions in the Study of Ageing and Later Life (pp. 87-102). Routledge.

National Board of Health and Welfare (Socialstyrelsen). (2019). Vård och omsorg om äldre: Lägesrapport 2019 (Care of Older People: Status Report 2019).

Neugarten, B. (1968). Middle Age and Aging. The University of Chicago Press.

Nordicom. (2019). The Media Barometer 2018: Some Basic Tables. https://www.nordicom.gu.se/sites/default/files/bilder/Mediefakta/Medie barometern/english_mbar_2018_5_2.pdf

Officer, A., \& de la Fuente-Núñez, V. (2018). A global campaign to combat ageism. Bulletin of the World Health Organization, 96(4), 295-296.

Olsson, E.-K., \& Eriksson, M. (2016). The logic of public organizations' social media use: Toward a theory of "social mediatization." Public Relations Inquiry, 5(2), 187-204.

Orgad, S. (2012). Media Representation and the Global Imagination. Polity Press.

Oró-Piqueras, M., \& Marques, S. (2017). Images of old age in YouTube: Destabilizing stereotypes. Continuum, 31(2), 257-265.

Pallas, J., Fredriksson, M., \& Wedlin, L. (2016). Translating institutional logics: When the media logic meets professions. Organization Studies, 37(11), 1661-1684.

Palmore, E. (2016). Age stratification. In E. B. Palmore, L. Branch, \& D. Harris (Eds.), Encyclopedia of Ageism (pp. 17-18). Routledge.

Palmore, Erdman. (1999). Ageism: Negative and Positive (2nd Edn.). Springer.

Petersen, L. N. (2017). 'Generation Conviviality'. The role of media logic in Television production for elderly audiences. Nordicom Review, 38(s1), 25-38.

Porlezza, C. (2019). Accuracy in journalism. In Oxford Research Encyclopedia of Communication. Oxford University Press. https://oxfordre.com/communication/view/10.1093/acrefore/97801902 28613.001.0001/acrefore-9780190228613-e-773

Prieler, M., Kohlbacher, F., Hagiwara, S., \& Arima, A. (2015). The representation of older people in television advertisements and social change: The case of Japan. Ageing and Society, 35(4), 865-887.

Ranzijn, R. (2004). Role ambiguity: Older workers in the demographic transition. Ageing International, 29(3), 281-307. 
Ranzijn, R. (2010). Active ageing - Another way to oppress marginalized and disadvantaged elders? Journal of Health Psychology, 15(5), 716-723.

Riley, M., Johnson, M., \& Foner, A. (1972). Age strata in the society. In M. Riley, M. Johnson, \& A. Foner (Eds.), Aging and Society, Volume 3: A Sociology of Age Stratification (pp. 397-456). Russell Sage Foundation.

Robinson, T., \& Popovich, M. (2003). Older adults' perceptions of offensive senior stereotypes in magazine advertisements: Results of AQ method analysis. Educational Gerontology, 29(6), 503-519.

Rose, G. (2016). Content analysis and cultural analytics: Finding patterns in what you see. In Visual Methodologies: An Introduction to Researching with Visual Materials (4th Edn., pp. 85-105). Sage.

Rowland, D. T. (2012). The third age. In Population Aging (pp. 167-181). Springer.

Roy, A., \& Harwood, J. (1997). Underrepresented, positively portrayed: Older adults in television commercials. Journal of Applied Communication Research, 25(1), 39-56.

Saul, D. J. (2014). 3 Million Teens Leave Facebook in 3 Years: The 2014 Facebook Demographic Report. IStrategyLabs. http://istrategylabs.com/2014/01/3-million-teens-leave-facebook-in-3years-the-2014-facebook-demographic-report/

Schaffel, G. (2018). It's Official: Facebook is Becoming the Platform for You. The American Association of Retired Persons (AARP). https://www.aarp.org/home-family/personal-technology/info2018/facebook-users-age-fd.html

Schrott, A. (2009). Dimensions: 'Catch all label or technical term'. In K. Lundby (Ed.), Mediatization: Concept, Changes, Consequences (pp. 4161). Peter Lang.

Scott, W. R. (2003). Institutional carriers: Reviewing modes of transporting ideas over time and space and considering their consequences. Industrial and Corporate Change, 12(4), 879-894.

Scott, W. R. (2014). Institutions and Organizations: Ideas, Interests, and Identities (4th Edn.). Sage.

Sedláková, R. (2005). What would we know about seniors if we knew them only from Czech media? An analysis of representations of senior in the nationwide media. In H. Rusu \& B. Voicu (Eds.), Perspectives on the European Postcommunist Societies (pp. 59-64). Psihomedia Publishing House.

Signorielli, N. (2004). Aging on television: Messages relating to gender, race, and occupation in prime time. Journal of Broadcasting \& Electronic Media, 48(2), 279-301.

Simcock, P., \& Lynn, S. (2006). The invisible majority? Older models in UK 
television advertising. International Journal of Advertising, 25(1), 87106.

Snellman, F. (2016). Whose ageism? The reinvigoration and definitions of an elusive concept. Nordic Psychology, 68(3), 148-159.

Soto-Perez-de-Celis, E. (2020). Social media, ageism, and older adults during the COVID-19 pandemic. EClinicalMedicine, 29-30, 100634.

Strömbäck, J., \& Esser, F. (2014). Mediatization of politics: Towards a theoretical framework. In J. Strömbäck \& F. Esser (Eds.), Mediatization of Politics (pp. 3-28). Palgrave Macmillan.

Strömbäck, Jesper. (2008). Four phases of mediatization: An analysis of the mediatization of politics. The International Journal of Press/Politics, 13(3), 228-246.

Sweney, M. (2018). Is Facebook for old people? Over-55s flock in as the young leave. The Guardian. https://www.theguardian.com/technology/2018/feb/12/is-facebook-forold-people-over-55s-flock-in-as-the-young-leave

Swift, H., \& Steeden, B. (2020). Exploring Representations ofOld Age and Ageing. https://www.ageing-better.org.uk/sites/default/files/202003/Exploring-representations-of-old-age.pdf

Szmigin, I., \& Carrigan, M. (1999). The representation of older people in advertisements: Ageism in advertising. Market Research Society Journal, 4l(3), 1-16.

The State Council Information Office of the People's Republic of China. (2020). Fighting COVID-19: China in Action. http://english.www.gov.cn/news/topnews/202006/07/content_WS5edc 559ac6d066592a449030.html

Thornton, P. H., \& Ocasio, W. (2008). Institutional logics. In R. Greenwood, C. Oliver, T. B. Lawrence, \& R. E. Meyer (Eds.), The Sage handbook of organizational institutionalism (pp. 99-128). Sage.

Trentham, B., Sokoloff, S., Tsang, A., \& Neysmith, S. (2015). Social media and senior citizen advocacy: An inclusive tool to resist ageism? Politics, Groups, and Identities, 3(3), 558-571.

UNECE. (2012). Images of Older Persons (No. 12; UNECE Policy Brief on Ageing). https://unece.org/DAM/pau/age/Policy_briefs/ECE-WG-113.pdf

United Nations. (2002). The Madrid International Plan of Action on Ageing and the Political Declaration.

United Nations DESA. (2016). Taking a Stand against Ageism. https://www.un.org/development/desa/en/news/social/taking-a-standagainst-ageism.html

Uprichard, E. (2008). Children as "being and becomings": Children, 
childhood and temporality. Children \& Society, 22(4), 303-313.

Van Dijck, J., \& Poell, T. (2013). Understanding social media logic. Media and Communication, 1(1), 2.

van Dyk, S., Lessenich, S., Denninger, T., \& Richter, A. (2013). The many meanings of "active ageing": Confronting public discourse with older people's stories. Recherches Sociologiques et Anthropologiques, 44(1), 97-115.

Vasileiou, K., Barnett, J., Thorpe, S., \& Young, T. (2018). Characterising and justifying sample size sufficiency in interview-based studies: Systematic analysis of qualitative health research over a 15 -year period. BMC Medical Research Methodology, 18(1), 148.

Vickers, K. (2007). Aging and the media. Californian Journal of Health Promotion, 5(3), 100-105.

Vidovićová, L., \& Honelová, M. (2018). A case study of ageism in political debates: Are social media a latent source of generational hatred? Slovak Ethnology/Slovensky Narodopis, 66(2), 203-220.

Visual Sweden. (n.d.). About Visual Sweden. Retrieved April 24, 2020, from https://www.visualsweden.se/en/om/

Wahl, H.-W., \& Ehni, H.-J. (2020). Advanced old age as a developmental dilemma: An in-depth comparison of established fourth age conceptualizations. Journal of Aging Studies, 55, 100896.

WHO. (2020). Campaigning to Tackle Ageism: Current Practices and Suggestions for Moving Forward. https://cdn.who.int/media/docs/default-source/3rd-edlsubmissions/campaigning-to-tackleageism.pdf?sfvrsn=c89079ac_1\&download=true

Wiles, R., Prosser, J., Bagnoli, A., Clark, A., Davies, K., Holland, S., \& Renold, E. (2008). Visual Ethics: Ethical Issues in Visual Research. http://eprints.ncrm.ac.uk/421/1/MethodsReviewPaperNCRM-011.pdf

Williams, A., Wadleigh, P. M., \& Ylänne, V. (2010). Images of older people in UK magazine advertising: Toward a typology. The International Journal of Aging and Human Development, 71(2), 83-114.

Williams, A., Ylänne, V., Wadleigh, P. M., \& Chen, C.-H. (2010). Portrayals of older adults in UK magazine advertisements: Relevance of target audience. Communications, 35(1), 1-27.

Wykes, M. (1998). Reviewed work: Representation: Cultural representations and signifying practices by Stuart Hall. Key Words: A Journal of Cultural Materialism, 1, 104-107.

Xu, W. (2019). Portrayal of life stages on Swedish municipal media: A life course perspective. Vista - Revista de Cultura Visual $N^{o} 4$ Cultura Visual, Digital e Mediática: Imagens Entre Gerações, 4, 93-115. 
Ylänne, V. (2015). Representations of ageing in the media. In J. Twigg \& W. Martin (Eds.), Routledge Handbook of Cultural Gerontology (pp. 369376). Routledge.

Ylänne, Virpi, Williams, A., \& Wadleigh, P. M. (2010). Ageing well? Older people's health and well-being as portrayed in UK magazine advertisements. International Journal of Ageing and Later Life, 4(2), 33-62.

Zhang, Y. B., Harwood, J., Williams, A., Ylänne-McEwen, V., Wadleigh, P. M., \& Thimm, C. (2006). The portrayal of older adults in advertising. Journal of Language and Social Psychology, 25(3), 264-282. 


\section{Appendices}

Appendix 1. Interview guide

\begin{tabular}{|l|l|}
\hline Respondent name: & ID number: Archive \\
\hline Position: & Interview date: \\
\hline Institution/division: & Interview place: \\
\hline Media account: & Researcher(s): \\
\hline Years of work experience: & \\
\hline
\end{tabular}

Main topical area 1: Source of photos

1. What do you think about the role of photos based on your previous working experiences at the municipality?

2. Where did you usually look for/receive photos for municipal social media? E.g., specialist photographers/colleagues, citizens, image websites ...

3. In your dataset of stock photos, which life stage do you think is the most under-represented and the most over-represented?

4. What do you think about the power of source?

Main topical area 2: Personal attitudes about life stages in photos

5. In your opinion, what counts as a good picture of infants, children, adolescents, adults and older people? (e.g. social interaction, activities, physical settings, objects)

6. What kinds of photos do you perceive as stereotypical photos of older people?

7. Do you have any photos that challenge stereotypical photos of older people?

8. What do you think about the influences of photos in impacting upon public opinion about age?

Main topical area 3: Selection

9. In your opinion, how does the municipality promote ageinclusiveness and diversity in the selection of photos displayed in the media? E.g. work guidelines, training ...

10. How does feedback from citizens influence your work?

11. In your opinion, are there any other external forces that influence your selecting and publishing the photos? E.g. business interests ... 
Main topical area 4: Publishing

12. How do you decide upon an order/layout of the selected photos?

13. How would you write a description of the photo and how to depict the human figures presented in the photos?

Rounding off questions

14. What you think could be improved concerning XXXX? (depending on who is being interviewed and what is in focus)

15. Is there anything important concerning XXXX that I have not asked about that you would like to say? 
Appendix 2. Information letter and consent form

Information for Research Participants

1.

Background and purpose

2. Inquiry concerning participation

3. How will the study be conducted?

4. Are there any advantages?

5. Dealing with data and confidentiality
This research project, entitled: Ageism in the Media, is a three-year doctoral project at Linköping University. It aims to explore (a) the ways in which Swedish municipalities portray citizens at different life stages in municipal new media; and (b) how Swedish municipalities produce a public image of older people in new media through the routine work practices of media professionals.

You are being invited to take part in this research because your work experience in municipalities as a media professional can contribute a lot to our knowledge about the production processes for communication materials in the media.

This research will involve your participation in an interview that will take about one hour. The interview will be audio-recorded, and a transcript will be produced.

The results of this research may potentially advance our knowledge of ageism and age stereotypes in the media, and may lead to better age-inclusive media and communication outcomes.

Your personal data controller is Linköping University, 58183 Linköping, corporate identification number 202100-3096.

We process your personal data in the form of your name, email address and audio recordings.

Access to the interview transcript will be limited to the researchers on this project.

Your personal information will be stored for 10 years in accordance with the research regulations of Linköping University. Audio files will be safely stored on Linköping University's internal server; transcripts will be safely stored in physical files. 
You are entitled to have access to information from the records used; and you have the right to require the correction of any incorrect information.

Any summary interview content, or direct quotations from the interview, that are made available through academic publications or other academic outlets will be anonymized; only nonpersonal information will be disclosed.

6. How do I You may send inquiries to Wenqian $\mathrm{Xu}$ obtain (wenqian.xu@liu.se) to ask for access to your information personal data (the results of the individual analyses) about the and the results of the entire study (e.g., publications results of the in academic journals).

study?

7.

Voluntariness

Your participation in this research is voluntary, and you may withdraw your consent at any time without giving a reason.

For withdrawal of consent/questions/complaints, please contact: Wenqian Xu (wenqian.xu@liu.se +46 700896448).

\section{Consent Form}

I have been given information about the project Ageism in the Media, have been given the opportunity to ask questions, have received answers to them and have given my consent to my data being processed as stated in the information sheet.

\begin{tabular}{|l|l|}
\hline Place & Signature of participant \\
\hline Date Day/month/year & Printed Name \\
\hline
\end{tabular}




\section{Articles}

The articles associated with this thesis have been removed for copyright reasons. For more details about these see:

http://urn.kb.se/resolve?urn=urn:nbn:se:liu:diva-175019 


\section{FACULTY OF ARTS AND SCIENCES}

Linköping Studies in Arts and Sciences No. 808, 2021 Department of Culture and Society

Linköping University

SE-581 83 Linköping, Sweden

www.liu.se 